\title{
QUALIDADE MICROBIOLÓGICA DO LEITE E DO SORVETE DE MASSA DE UMA INDÚSTRIA DE PEQUENO PORTE DO \\ MUNICÍPIO DE PIRACICABA - SP
}

\section{ROBERTA TERESA RIZZO-BENATO}

\author{
Dissertação apresentada à Escola Superior de \\ Agricultura "Luiz de Queiroz", Universidade de São \\ Paulo, para obtenção do título de Mestre em Ciências, \\ Área de Concentração: Ciência e Tecnologia de \\ Alimentos.
}

P I R A C I C A B A

Estado de São Paulo - Brasil

Setembro - 2004 


\title{
QUALIDADE MICROBIOLÓGICA DO LEITE E DO SORVETE DE MASSA DE UMA INDÚSTRIA DE PEQUENO PORTE DO MUNICÍPIO DE PIRACICABA - SP
}

\author{
ROBERTA TERESA RIZZO-BENATO \\ Licenciatura em Ciências Biológicas
}

Orientador: Prof. Dr. CLAUDIO ROSA GALLO

\begin{abstract}
Dissertação apresentada à Escola Superior de Agricultura "Luiz de Queiroz", Universidade de São Paulo, para obtenção do título de Mestre em Ciências, Área de Concentração: Ciência e Tecnologia de Alimentos.
\end{abstract}

P I R A C I C A B A

Estado de São Paulo - Brasil

Setembro - 2004 
Dados Internacionais de Catalogação na Publicação (CIP) DIVISÃO DE BIBLIOTECA E DOCUMENTAÇÃO - ESALQ/USP

\section{Rizzo-Benato, Roberta Teresa}

Qualidade microbiológica do leite e do sorvete de massa de uma indústria de pequeno porte do município de Piracicaba - SP / Roberta Teresa Rizzo-Benato. - - Piracicaba, 2004 62 p. : il.

Dissertação (Mestrado) - - Escola Superior de Agricultura Luiz de Queiroz, 2004. Bibliografia.

1. Contaminação de alimentos 2 . Higiene de alimentos 3. Indústria de alimentos 4. Leite 5. Microbiologia de alimentos 6 Sorvete I. Título

CDD 637.4 
Ao Maurício,

Por ter me ensinado a ver a vida de uma forma diferente

Á Olívia Castellari Rizzo (in memoriam) em quem me espelho

\section{DEDICO}

Aos meus queridos pais,

Pedro e Neusa, Pela dádiva da vida 


\section{AGRADECIMENTOS}

À Deus, pela minha saúde, por me guiar e me carregar no colo nas horas mais difíceis;

Aos meus pais, pela educação e exemplo de vida;

Ao meu irmão Júnior, pelo carinho;

Ao eterno namorado Maurício Benato, pela paciência, cumplicidade, compreensão e apoio em todos os momentos;

À família Benato; Denise, Ricardo e Renata Maia por estarem sempre ao meu lado e à Lilia, por ser tão especial;

Aos amigos e profissionais Marielena e Álvaro Sousa, pessoas essenciais na realização deste trabalho; por me proporcionarem o acesso à indústria e me ensinarem e auxiliarem em todo o decorrer do trabalho;

Ao profissional Claudiney Betiol, pela amizade construída e auxílio na produção do sorvete;

À Escola Superior de Agricultura "Luiz de Queiroz”, de modo particular ao Departamento de Agroindústria, Alimentos e Nutrição, pelas facilidades oferecidas para a execução deste trabalho;

À Prof ${ }^{\mathrm{a}} \mathrm{Dr}^{\mathrm{a}}$ Marília Oetterer, pelo incentivo, apoio e oportunidade dada ao meu ingresso ao mestrado, sempre acreditando e confiando em minha capacidade;

Ao Prof. Dr. Cláudio Rosa Gallo, exímio profissional, pelos ensinamentos na orientação, pelo carinho, amizade, compreensão, tornando possível a elaboração deste trabalho;

As técnicas e amigas Cecília Helena Nogueira, Denise Baptista e Rosalina Ocangne pela ajuda, me auxiliando e colaborando nas análises microbiológicas; 
Ao Laboratório de Microbiologia de Alimentos da ESALQ/USP pela contribuição com os materiais utilizados;

À Prof ${ }^{\mathrm{a}}$ Dr $^{\mathrm{a}}$ Marta Helena Fillet Spoto, pela confiança, amizade e auxílio no decorrer dos anos;

Aos professores Drs. Valmir Eduardo Alcarde, Ernani Porto, Gilma Lucazechi Sturion e Taís Lacerda, pelas sugestões e auxílio nas correções;

Ao Engenheiro Agrônomo Marcelo Corrêa Alves, pela análise estatística e pela valiosa ajuda nas explicações;

À Prof ${ }^{\mathrm{a}} \mathrm{Dr}^{\mathrm{a}}$ Fernanda Bacellar amiga e profissional, pelo auxílio nas traduções;

À amiga e companheira, Ivani Marchetto Moreno por me acompanhar em todos os momentos;

À amiga Juliana Antunes Galvão, que me acompanha desde a graduação, minha principal alavanca nos estudos, pelo incentivo nos momentos mais difíceis;

Ao amigo Aelson Aloir Santana Brum, pelo carinho e ajuda em todos os momentos;

Aos amigos e companheiros de trabalho, Rubens César Pereira e Luiz Carlos Rodrigues pela ajuda nas formatações das figuras;

À todos que me ajudaram no experimento, Ana Paula Aguiar, Fabiana Cerri, Daniela Maggiotto, Chantal e Eduardo Salán, meu eterno reconhecimento;

Aos amigos do Programa de Pós Graduação em Ciência e Tecnologia de Alimentos, Ana Cecília, Eloíse, Fabiana, Renata, Selma, de modo especial, Érika, Débora, Lia, Ricardo e Marielen, por todos os momentos compartilhados;

À Midiam Gustinelli pela constante preocupação em me ajudar;

Às bibliotecárias: Beatriz e Ligiana pela amizade e serviços prestados;

Às secretárias Gislaine Nóbilo, Márcia Bertarelli e Regina Lourenço, pela amizade e ajuda sempre que necessária;

Aos Drs. Carlos Cais, Deise Freire, Jane e Peter Liu pela atenção, carinho e cuidados especiais dados até hoje;

À todos os funcionários do Departamento de Agroindústria, Alimentos e Nutrição. 


\section{SUMÁRIO}

\begin{tabular}{|c|c|}
\hline & gina \\
\hline ח & \\
\hline SUMMARY.. & \\
\hline 1 INTRODUÇÃO.. & \\
\hline 2 REVISÃO DE LITERATURA... & \\
\hline 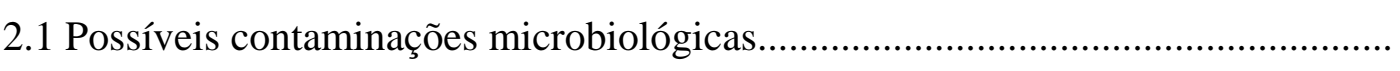 & \\
\hline 2.1.1 Contaminações microbiológicas advindas do leite................ & \\
\hline 2.1.2 Contaminações microbiológicas advindas do sorvete...... & \\
\hline 2.2 Microrganismos comumente encontrados no leite e no sorvete.... & \\
\hline 2.2.1 Psicrotróficos..... & \\
\hline 2.2.2 Staphylococcus...... & 10 \\
\hline 2.2.3 Salmonella................ & 11 \\
\hline 2.2.4 Coliformes totais..... & 12 \\
\hline 2.2.5 Escherichia coli... & 13 \\
\hline 2.3 Tratamentos térmicos utilizados no processamento do sorvete.... & 14 \\
\hline 2.3.1 Pasteurização... & 14 \\
\hline 2.3.2 Refrigeração....... & 15 \\
\hline 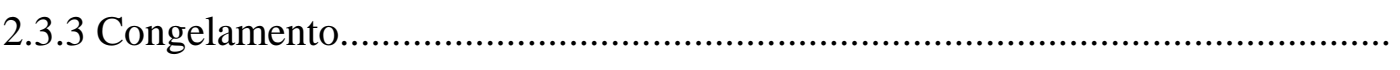 & 15 \\
\hline 2.4 Efeito das temperaturas de congelação e refrigeração sobre os microrganismos. & 16 \\
\hline 3 MATERIAL E MÉTODOS.. & 18 \\
\hline 3.1 Origem e obtenção das amostras.... & 18 \\
\hline 3.2 Processamento do sorvete...... & 19 \\
\hline Análises & \\
\hline
\end{tabular}


3.4 Preparo das amostras................................................................................... 24

3.4.1 Amostras de leite..................................................................................... 24

3.4.2 Amostras de sorvete................................................................................... 24

3.5 Microrganismos analisados......................................................................... 25

3.5.1 Número Mais Provável (NMP) de coliformes totais e fecais............................... 25

3.5.2 Presença/ausência de Salmonella.................................................................. 27

3.5.3 Enumeração de Staphylococcus coagulase positiva............................................. 29

3.6 Análise estatística...................................................................................... 30

4 RESULTADOS E DISCUSSÃO.............................................................. 32

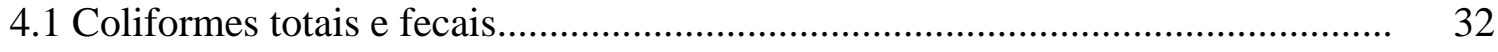

4.2 Salmonella ......................................................................................... 4

4.3 Staphylococcus coagulase positiva................................................................ 49

5 CONCLUSÕES....................................................................................... 52

REFERÊNCIAS BIBLIOGRÁFICAS........................................................... 54 


\title{
QUALIDADE MICROBIOLÓGICA DO LEITE E DO SORVETE DE MASSA DE UMA INDÚSTRIA DE PEQUENO PORTE DO MUNICÍPIO DE PIRACICABA - SP
}

\author{
Autora: ROBERTA TERESA RIZZO BENATO \\ Orientador: Prof. Dr. CLAUDIO ROSA GALLO
}

\section{RESUMO}

Pela demanda elevada de sorvetes a base de leite no mercado, e ocasionais relatos de intoxicação alimentar por esse alimento, este trabalho objetivou avaliar a qualidade microbiológica de sorvetes, bem como a de sua principal matéria-prima, o leite. Foram analisadas 24 amostras de leite e 36 de sorvetes dos sabores de maior procura, creme e chocolate. Análises microbiológicas foram realizadas para a determinação do Número Mais Provável (NMP) de coliformes totais e fecais, a enumeração de Staphylococcus coagulase-positiva e a pesquisa de Salmonella spp, análises exigidas pela Agência Nacional de Vigilância Sanitária (ANVISA) (Brasil, 2001). Realizou-se, também, a comparação entre os caldos Escherichia coli - EC (Difco 0314-01-0) e Caldo Verde Brilhante Lactose Bile 2\% - CVBLB (Difco 0007-01-2) utilizados no teste confirmativo para a detecção de coliformes fecais, havendo diferença significativa $(p<0,05)$ entre eles na enumeração do NMP de coliformes fecais. Com base nos resultados obtidos, pode-se afirmar que 58,3\% das amostras de leite e 19,4\% das amostras de sorvetes analisadas apresentaram valores para coliformes fecais acima dos tolerados pela referida legislação quando se utilizou o CVBLB e 70,8\% das amostras de leite e 30,6\% das amostras de sorvetes apresentaram NMP de coliformes fecais acima 
dos permitidos pela legislação quando se utilizou o caldo EC. Staphylococcus coagulasepositiva foi detectado em apenas uma amostra de leite $(4,2 \%)$ e em duas amostras de sorvete (5,6\%) e todas as amostras analisadas não apresentaram Salmonella em $25 \mathrm{~mL}$ ou $25 \mathrm{~g}$. 


\title{
MICROBIOLOGICAL QUALITY OF MILK AND ICE CREAM OF A SMALL INDUSTRY OF THE DISTRICT OF PIRACICABA - SP, BRAZIL
}

\author{
Author: ROBERTA TERESA RIZZO BENATO \\ Adviser: Prof. Dr. CLAUDIO ROSA GALLO
}

\section{SUMMARY}

Due to the high demand of milk base ice cream in the market and occasional milk intoxication, this work aimed to evaluate the microbiological quality of vanilla and chocolate ice cream production, as well as its raw material, the milk. Comparisons of the media of Escherichia coli broth - EC (Difco 0314-01-0) and brilliant green bile lactose broth 2\% - BGB (Difco 0007-01-2) were used in the confirmation test for fecal coliform counts. The sample microbiological analyses carried out were the counts of total and fecal coliforms, the examination for positive-coagulase Staphylococcus and Salmonella spp, all of them determined by the present brazilian legislation. Basing on the obtained results, the milk exceeded values in $58.3 \%$ and the ice cream in $19.4 \%$ of the samples analyzed for fecal coliforms using BGB and 70.8\% and 30.6\%, respectively using EC. Staphylococcus was detected in just one milk sample (4.2\%) and two ice cream samples (5.6\%) and for Salmonella, all of the samples presented absence of that microorganism. There was a significant difference $(\mathrm{p}<0.05)$ between the EC and BGB media comparisons. 


\section{INTRODUÇÃO}

As doenças veiculadas por alimentos têm sido consideradas um dos problemas mais importantes em saúde pública. A origem e investigação de doenças alimentares são complexas, relacionadas a diversos fatores ligados à cadeia epidemiológica de enfermidades transmissíveis que envolvem a tríade agente, meio e ambiente. Dentre os fatores comumente associados às doenças de origem alimentar, merecem destaque as mudanças das características demográficas de certas regiões, hábitos culturais, tecnologia empregada desde a produção até a comercialização dos alimentos, baixo incentivo governamental em programas de vigilância de alimentos, tendências globais de mercado e mecanismos de virulência e adaptação dos microrganismos (Ribeiro et al., 1999).

É possível que a origem do sorvete e outros produtos similares gelados sejam provenientes da mistura de gelo e mel como menciona o Velho Testamento (Rothwell, 1990).

Varnam \& Sutherland (1994) descrevem que a criação de sobremesas geladas iniciou-se com a mistura de neve, frutas e suco de frutas. Essa antiga prática culinária provavelmente, originou-se na China. As sobremesas geladas foram introduzidas na Europa no final do século XIII, mas durante 500 anos somente a aristocracia foi beneficiada com essa iguaria.

Em 1851 iniciou-se a produção em grande escala, expandindo rapidamente a indústria pela introdução da refrigeração mecânica e o desenvolvimento das máquinas produtoras de sorvete, como o homogeneizador em 1899 e o congelamento contínuo em 1929 (Rothwell, 1990; Varnam \& Sutherland, 1994). 
O sorvete a base de leite, desenvolvido na Europa, foi introduzido no norte da América há aproximadamente 250 anos, sendo adotado pelos norte-americanos que se encarregaram de melhorá-lo, a ponto de se constituir num dos principais ítens de sua dieta (Mosquim, 1999).

Segundo Warke et al. (2000), o sorvete tornou-se um dos principais produtos das indústrias de leite e de grande interesse público.

De acordo com Rothwell (1990), o consumo de sorvete varia de país a país e isto não é completamente dependente das condições climáticas. Um grande exemplo é o consumo per capita de gelados comestíveis nos Estados Unidos que supera a 20 litros por ano, enquanto no Brasil, somente ultrapassa a 2 litros no eixo Rio - São Paulo, onde se concentra a população de maior poder aquisitivo (Mosquim, 1999). Seu maior consumo ocorre no verão, quando também é maior a produção de leite.

Quanto à composição, Mosquim (1999) cita que o sorvete a base de leite deve conter, no mínimo, $10 \%$ de gordura e $20 \%$ de sólidos totais, tratando-se, portanto, de um alimento lácteo bastante saudável e nutritivo, que pode ser consumido em qualquer época do ano. Não só pelo alto valor energético, como também por conter as vitaminas do leite em maiores concentrações, como vitamina A, D, E, niacina e riboflavina, o sorvete a base de leite é recomendável para crianças em crescimento que necessitam de aumento de peso, e para adolescentes, devido à maior velocidade de crescimento de seus ossos.

Além do valor nutricional, o sorvete tem a característica de alta digestibilidade, quando bem homogeneizado. Esses fatores associados a outras características como sabor doce e textura macia, fazem do sorvete um alimento ideal para todas as idades. Pela fácil assimilação, o sorvete é excelente para idosos, pessoas de apetite difícil e em casos de úlceras e gastrites crônicas, o sorvete exerce função terapêutica, onde, pelo resfriamento, ocorre o descongestionamento da mucosa gástrica inflamada e estimula a secreção das enzimas digestivas. Enfim, como se pode notar, nunca se reuniu tantos atributos em um só alimento quanto no sorvete, onde juntou-se a nutrição com o prazer (Castilho, 1992). 
O sorvete preparado com leite é um produto delicado, que pode facilmente estragar se não for mantido sob congelamento. Sua mistura básica é pasteurizada, porém contaminações secundárias com Staphylococcus aureus, Salmonella, entre outros microrganismos podem ocorrer, como tem sido relatado freqüentemente, por falta de higiene na fabricação do sorvete (Frank, 1992).

O consumidor não associa que o sorvete ingerido em momentos de lazer e descontração possa apresentar riscos de natureza microbiológica, pois este julga que a baixa temperatura assegure sua inocuidade. Mas, como a resistência de microrganismos ao congelamento é muito variável, se houver alguma contaminação da matéria-prima ou no momento do processamento e os microrganismos forem resistentes, podem permanecer viáveis e serem ingeridos pelos consumidores (Pinto et al., 2000), podendo vir a causar toxinfecções.

Com o intuito de contribuir com dados a respeito das condições higiênicosanitárias desse alimento, o presente trabalho têve como objetivo avaliar a qualidade microbiológica de sorvetes a base de leite, elaborados por uma indústria de pequeno porte do Município de Piracicaba - SP, bem como da sua principal matéria-prima, o leite, verificando se os produtos estariam de acordo com os padrões microbiológicos exigidos pela legislação nacional vigente (ANVISA) Brasil (2001). Ainda, comparar a enumeração de coliformes fecais utilizando-se os caldos de cultivo Caldo Verde Brilhante Lactose Bile 2\% - CVBLB e caldo Escherichia coli - EC. 


\section{REVISÃO DE LITERATURA}

De acordo com Brasil (1996) e Mosquim (1999), os gelados comestíveis, são alimentos obtidos por congelamento, a partir de uma mistura básica, sob contínua agitação, pasteurizada, composta de ingredientes lácteos ou não, com ou sem a adição de outros ingredientes ou substâncias como: açúcares, corantes, aromatizantes, estabilizantes e emulsificantes, visando atender aos padrões definidos para sólidos totais e overrun (incorporação de ar) em condições que garantam a conservação do produto, no estado congelado, ou parcialmente congelado, durante a armazenagem, o transporte e a entrega ao consumo.

Embora o estado congelado do sorvete e dos produtos afins evite a preocupação do fabricante em relação à ação bacteriana no produto acabado, isto não elimina o risco de transmissão de microrganismos patogênicos ou toxinas através desses alimentos (Marshall \& Arbuckle, 2000).

Chaves (1993), afirma que os métodos de processamento, tais como, manipulação e tratamento dos alimentos, sempre criam novos problemas microbiológicos.

O mesmo autor cita que a contaminação maior ocorrerá por microrganismos que chegam ao alimento durante o seu processamento, desde a escolha da matéria-prima até a operação final, quando o produto estará pronto para o consumo. Assim, pode-se concluir que o alimento, cuja preparação exige muita manipulação, tem maior chance de ser contaminado, se não forem observados os cuidados de assepsia.

Varnam \& Sutherland (1994), afirmam que os microrganismos ficam impossibilitados de crescer em sorvetes estocados em temperaturas corretas, embora muitos sobrevivam por grandes períodos. Portanto, as considerações microbiológicas 
envolvem primeiramente a eliminação de células vegetativas dos patógenos por pasteurização e a prevenção de recontaminação em todos os pontos de venda, principalmente por microrganismos termodúricos formadores de toxinas, prevenindo seu crescimento antes do congelamento.

Ainda hoje, os gelados comestíveis não têm sido considerados como uma séria fonte de infecção bacteriana, por se constituir de um alimento congelado. Porém, a resistência de microrganismos ao congelamento é muito variável, pois o congelamento não provoca necessariamente morte de todos os microrganismos presentes e muitos sobrevivem em diferentes estados fisiológicos (Carvalho et al., 1995; Pinto et al., 2000).

Para Warke et al. (2000), devido a falta de eficiência no armazenamento congelado, e as condições climáticas que prevalecem em países tropicais, há grande probabilidade de oscilação de temperatura durante transporte e distribuição de sorvete. Sob tal condição, psicrotróficos podem se proliferar e eventualmente ocasionar uma intoxicação.

A temperatura mais baixa na qual se constatou o crescimento microbiano em alimento foi a de $-34^{\circ} \mathrm{C}$. Os microrganismos que normalmente crescem em temperaturas inferiores a $0^{\circ} \mathrm{C}$ são os bolores e leveduras, apesar de já ter sido relatado o crescimento de bactérias em temperaturas de $-12^{\circ} \mathrm{C}$ e $-20^{\circ} \mathrm{C}$. O sorvete é um dos alimentos que permitem o crescimento microbiano a temperaturas abaixo de $0^{\circ} \mathrm{C}$ (Franco \& Landgraf, 1996).

\subsection{Possíveis contaminações microbiológicas}

Chaves (1993), cita algumas fontes de contaminação dos alimentos, como o homem no manejo dos produtos alimentícios, em operações de processamento e no momento do consumo; superfícies que entram em contato com os alimentos; os equipamentos, máquinas e vasilhames usados nas operações de industrialização e a água, que é um dos fatores de maior importância na indústria de alimentos, uma vez que é usada em grande quantidade nas lavagens. 
Segundo Pinto et al. (2000), as fontes de contaminação mais comuns são matérias-primas, instalações, equipamentos, utensílios e manipuladores. Os microrganismos contaminantes de um alimento podem ainda se multiplicar por falhas durante o processamento, em etapas anteriores ao congelamento e permanecerem viáveis no produto.

Tanto o leite, como os sorvetes elaborados a partir do leite, podem ser conservados de muitas formas distintas, algumas das quais supõe a destruição de uma parte dos microrganismos existentes e a inibição do crescimento do restante. Porém, alguns produtos lácteos têm um tempo de conservação limitado e muitos se alteram com facilidade se os procedimentos utilizados para conservá-los não forem apropriados (Frazier \& Westhoff, 1993).

\subsubsection{Contaminações microbiológicas advindas do leite}

O leite é um excelente meio de cultivo para uma grande quantidade de microrganismos, pelo seu elevado conteúdo de água, pelo seu $\mathrm{pH}$ próximo da neutralidade e por conter uma grande quantidade de nutrientes energéticos que se encontram na forma de açúcar do leite (lactose), de lipídeos, de citratos e de compostos nitrogenados de várias naturezas (proteínas, aminoácidos e outras substâncias) além dos sais minerais que os microrganismos necessitam (Frazier \& Westhoff, 1993).

A contaminação do leite pode ocorrer na ordenha e durante todo seu processo de manipulação até o armazenamento, portanto a qualidade de todos os produtos derivados do leite dependerá, basicamente, das condições microbiológicas da matériaprima (Franco \& Landgraf, 1996).

A pasteurização do leite destroe as bactérias com maior atividade acidificante, porém é possível que as bactérias lácticas termorresistentes sobrevivam, as quais podem dar origem a uma fermentação láctica se a temperatura de armazenamento do leite estiver suficientemente elevada (Frazier \& Westhoff, 1993).

Ainda, os mesmos autores afirmam que, devido à tendência do emprego de temperaturas de pasteurização cada vez mais elevadas, com maior freqüência, a flora 
microbiana que altera o leite pasteurizado é constituída por bacilos esporógenos termorresistentes que podem ser psicrotróficos.

Segundo Tamsut \& García (1989), as matérias-primas devem ser tão bem controladas quanto o processo de fabricação.

Na pesquisa feita por Pinto et al. (2000) os autores confirmam que, a maior contaminação em amostras de sorvete elaboradas com leite é devida a má qualidade da matéria-prima.

Em 2861 casos confirmados de toxinfecções alimentares na França (Buyser et al., 2001), 177 foram por leite e derivados onde, S. aureus foi responsável em 59\% e Salmonella em 19\%.

\subsubsection{Contaminações microbiológicas advindas do sorvete}

De acordo com Hoffmann et al. (2000), a microbiota dos sorvetes, antes do tratamento térmico, está relacionada com os ingredientes utilizados, sendo que de acordo com a legislação todos os gelados comestíveis elaborados com laticínios ou ovos serão obrigatoriamente pasteurizados. Por este motivo, com poucas exceções, não ocorreram nos últimos anos doenças causadas pela ingestão de sorvetes elaborados por estabelecimentos industriais e/ou comerciais e sim, por produtos caseiros, devido a práticas inadequadas de manuseio. Dentre essas práticas, pode-se citar a utilização de leite cru, creme e ovos contaminados, o emprego inadequado de tratamento térmico, contaminação através do ambiente ou mesmo por pessoas infectadas.

Varnam \& Sutherland (1994), confirmam que, até certo ponto, o sorvete tem a reputação de ser um alimento de alto risco. Isto é injustificado pela produção e comercialização de sorvetes em países desenvolvidos onde o registro de segurança, durante muitos anos foi bom, como no caso da Inglaterra onde o último surto envolvendo sorvetes ocorreu em 1955. Este recorde pode ser atribuído pelo uso de ingredientes de alta qualidade e o rígido controle de pasteurização da massa, bem como a higiene durante as operações subsequentes. 
Rothwell (1990), destaca certas intoxicações causadas por sorvete entre as décadas de 40 e 70, onde a legislação ainda não regularizava o uso de tratamento térmico para a mistura. Entre tantas, em 1945 houve a intoxicação de aproximadamente 700 pessoas por toxina estafilocócica na Inglaterra; em 1947 cerca de 210 casos relatados entre eles 4 mortes por Salmonella typhi em Aberystwyth; e outros casos envolvendo a bactéria Salmonella paratyphi.

Análises de patógenos específicos em sorvetes são em muitos casos, desnecessárias e tampouco desejáveis, devendo o esforço envolvido ser melhor empregado implementando procedimentos que garantam a segurança desse alimento (Varnam \& Sutherland, 1994). Segundo os mesmos autores, a adição de certos ingredientes após a pasteurização é potencial fonte de risco.

Segundo Falcão et al. (1983), os sorvetes contêm a microbiota proveniente dos ingredientes utilizados na sua preparação e aqueles à base de leite e ovos são potencialmente perigosos à saúde, pois se constituem em ótimos meios de cultura para a maioria dos microrganismos incluindo os patogênicos.

Frazier \& Westhoff (1993) destacam o uso de leite em pó na preparação do sorvete, onde numerosos casos de intoxicação alimentar atribuídos as salmonelas e aos estafilococos procedentes de leite em pó demonstram que estes patógenos sobrevivem no produto final.

Qualquer ingrediente contaminado, utilizado no processamento do sorvete, pode influenciar na qualidade do produto acabado, principalmente se esta é avaliada pelo número de bactérias que contém, ou por conter espécies de bactérias indesejáveis, como os coliformes (Frazier \& Westhoff, 1993).

Tamsut \& García (1989), descrevem que apesar dos sorvetes a base de leite serem um produto que passa pelos processos de pasteurização, maturação no frio, congelação e endurecimento, podem conter microrganismos patógenos e microrganismos causadores de deterioração.

Analisando sorvetes a base de leite, Carvalho et al. (1995) citam, que a composição química interfere na flora bacteriana, pois componentes crioprotetores tais como aminoácidos, glicerol, lactose, sais de caseína e proteínas do soro contidos no leite 
e presentes no sorvete, exercem um mecanismo protetor à sua flora bacteriana, mantendo a carga microbiana inicial igual por todo o tempo de estocagem, diferente do sorvete a base de suco de frutas.

Para Warke et al. (2000), a qualidade microbiológica do sorvete durante a venda depende principalmente, da manipulação do produto no local de produção, como também da eficiência e condições sanitárias durante o armazenamento congelado.

Reij \& Den Aantrekker (2004) citam que normalmente as rotas de contaminação dos alimentos processados são: matérias-primas, superfícies de contato com o alimento, o processamento do alimento, a manipulação e a distribuição.

\subsection{Microrganismos comumente encontrados no leite e no sorvete}

\subsubsection{Psicrotróficos}

De acordo com Frank (1992), psicrotróficos são organismos psicrotolerantes, ou seja, possuem habilidade para crescer em temperaturas entre $0^{\circ} \mathrm{C}$ a $35^{\circ} \mathrm{C}$ com temperatura ótima de $24^{\circ} \mathrm{C}$. Já para Thomas (1971), os organismos psicrotróficos, tratando de leite e derivados, são aqueles que têm atividade abaixo de $7^{\circ} \mathrm{C}$, temperaturas estas utilizadas na refrigeração e na conservação em câmaras frias, podendo causar alterações em leite e produtos lácteos, dependendo do tempo e da temperatura de refrigeração.

As bactérias psicrotróficas que comumente alteram o leite pertencem aos seguintes gêneros: Pseudomonas, Achromobacter, Flavobacterium, Alcaligenes, Enterobacter e Arthrobacter, sendo em sua maior parte bacilos Gram-negativos. Tais bactérias são raramente termodúricas e sua presença em leite comercial pasteurizado, indica uma contaminação posterior à pasteurização (Thomas, 1971).

O comportamento frente às baixas temperaturas varia conforme a bactéria envolvida. As bactérias Gram positivas são mais resistentes ao frio do que as Gramnegativas, como Escherichia, Pseudomonas, Alcaligenes, Salmonella e Vibrio. A 
destruição ou injúria é maior entre $-2^{\circ} \mathrm{C}$ e $-10^{\circ} \mathrm{C}$, quando comparada a temperaturas mais baixas, como $-15^{\circ} \mathrm{C}$ e $-30^{\circ} \mathrm{C}$ (Franco \& Landgraf, 1996; Leitão, 1988).

Embora a maioria das bactérias psicrotróficas (Gram-negativas) sejam destruídas pela pasteurização, sobrevivendo apenas a microbiota termodúrica para causar deterioração, as enzimas extracelulares das bactérias psicrotróficas podem resistir ao tratamento térmico, não sendo inativadas pelo processamento (Rothwell, 1990).

Como estas bactérias normalmente são conseqüência da manipulação de produtos derivados do leite, sua contaminação geralmente ocorre na pós-pasteurização (Rothwell, 1990).

A contaminação por psicrotróficos deve-se principalmente à higienização deficiente de superfícies em contato com o leite, ambientes em condições inadequadas de higiene, manipuladores e qualidade da água utilizada (Oviedo, 1996).

\subsubsection{Staphylococcus}

Geralmente os alimentos de origem animal, especialmente o leite e seus derivados, aparecem associados a surtos de toxinfecção alimentar, representando um problema para a saúde pública. O gênero Staphylococcus, por ser o principal agente etiológico da mastite bovina, e também agente causador de toxinfecção alimentar, devido a sua capacidade de produção de enterotoxinas, vem despertando maior interesse em doenças vinculadas a alimentos (Brabes, 1999).

No homem, o maior reservatório de Staphylococcus aureus são as fossas nasais e a cavidade orofaríngea, podendo se fazer presente na pele e lesões nela localizadas. Tratando-se de animais, estes podem desenvolver infecções estafilocócicas e muitos carreiam o microrganismo na narina. Entretanto, a mais expressiva possibilidade de produção de enterotoxinas em alimentos, através de estafilococos transferidos da fonte animal, parece estar vinculada a animais com mastite, sendo frequentemente observado no úbere e nos canais das tetas das vacas, podendo portanto, atingir facilmente o leite (Brabes, 1999; Gomes, 1994). 
Com isso, tornou-se comum o leite cru ou não pasteurizado ser considerado o maior veículo de transmissão de patógenos, incluindo S. aureus (Gomes, 1994).

O mesmo autor ainda cita que, praticamente todos os incidentes de envenenamento alimentar estafilocócico, incluindo aqueles causados pelos produtos lácteos, têm sido atribuídos ao $S$. aureus, que é o agente causador de intoxicação alimentar mais comum em todo o mundo.

Segundo Davis et al. (1973), todas as cepas patogênicas de Staphylococcus produzem uma enzima conhecida como coagulase, que é capaz de coagular o plasma, porém nem todas formam o mesmo tipo de colônia no mesmo meio de cultura. Assim, o teste de coagulase positiva é a melhor evidência de laboratório de que uma dada cepa de estafilococo seja patogênica para o homem.

Vanderzant \& Splittstoesser (1992) citam que além do S. aureus, existem mais duas espécies coagulase positivas, o $S$. intermedius e o $S$. hyicus subspécie hyicus.

Deste modo, alimentos que não tenham sido processados adequadamente e apresentem contagem bacteriológica dentro dos padrões legais, poderão vir a provocar intoxicação estafilocócica se, em algum estágio da produção, o $S$. aureus cresceu e produziu enterotoxina suficiente para causar a doença.

Segundo Roberts et al. (2000), existem diversos produtos além do leite cru, onde se pode encontrar o $S$. aureus, como o leite em pó, os alimentos pré-cozidos refrigerados e congelados, como também superfícies e recipientes.

Bryan et al. (1992) afirmam que a presença de Staphylococcus em sorvetes, representa contaminação durante a sua preparação.

\subsubsection{Salmonella}

As salmonelas são membros da família Enterobacteriaceae. Elas são bacilos Gram negativos crescendo aerobicamente e anaerobicamente em temperaturas ótimas de $37^{\circ} \mathrm{C}$ e prontamente exterminadas em temperaturas acima de $55^{\circ} \mathrm{C}$ (Hobbs \& Roberts, 1999). 
Elas podem ser isoladas do intestino das pessoas e dos animais, atingindo alimentos direta ou indiretamente através dos excrementos de animais na hora do abate, através do excremento das pessoas, ou de águas poluídas por dejetos; também nas cozinhas, elas podem ser transferidas dos alimentos crus para os cozidos através das mãos, superfícies, utensílios e outros equipamentos (Hobbs \& Roberts, 1999).

Quanto ao controle no preparo dos alimentos, deve-se fazer a separação dos alimentos crus dos cozidos, usando-se diferentes superfícies e equipamentos, para se prevenir a contaminação cruzada; as mãos podem também passar organismos de alimento para alimento; outro fator muito importante é a estocagem quente ou fria dos alimentos para se prevenir a multiplicação dessas bactérias (Hobbs \& Roberts, 1999).

Frank (1992) descreve que a Salmonella, se presente no sorvete, sobrevive por vários anos, pois suporta baixas temperaturas.

No ano de 1994, em Minnesota, estimou-se que 224.000 pessoas haviam tido gastroenterite devido ao consumo de sorvetes contaminados com Salmonella enteritidis (Hennessy et al., 1996).

\subsubsection{Coliformes totais}

O grupo de coliformes totais inclui as bactérias na forma de bastonetes Gram negativos, não esporogênicos, aeróbias ou anaeróbias facultativas, capazes de fermentar a lactose com produção de gás, em 24 a 48 h a $35^{\circ} \mathrm{C}$. O grupo inclui cerca de 20 espécies, dentre as quais encontram-se tanto bactérias originárias do trato gastrintestinal de humanos e outros animais de sangue quente, como também diversos gêneros e espécies de bactérias não entéricas, como Serratia e Aeromonas, por exemplo. Por essa razão, sua enumeração em água e alimentos é menos representativa como indicação de contaminação fecal, do que a enumeração de coliformes fecais ou Escherichia coli (Silva et al., 2000). 


\subsubsection{Escherichia coli}

A Escherichia coli é um membro da família Enterobacteriaceae apresentandose como um coco-bacilo Gram negativo, anaeróbio facultativo, com temperatura ótima

de $37^{\circ} \mathrm{C}$ e prontamente destruído em temperaturas acima de $55^{\circ} \mathrm{C}$. É geralmente encontrada no intestino humano e animal e pode ser isolada dos alimentos de origem animal (Hobbs \& Roberts, 1999; Ribeiro et al., 1999).

Embora sendo um habitante normal e inofensivo do intestino de homens e animais, algumas cepas são patogênicas em crianças, adultos e animais quando presentes em outras partes do corpo humano, como o trato urinário ou meninges aonde elas podem causar doenças, assim como intoxicações alimentares (Eley, 1994; Hobbs \& Roberts, 1999).

A contaminação dos alimentos se dá principalmente por contato com material fecal de animais infectados ou contato com superfícies sujas, contaminadas com a bactéria. Ainda não se sabe ao certo a dose infectiva necessária para provocar os sintomas a partir da ingestão de alimentos contaminados, porém de acordo com dados obtidos de surtos, a dose infectiva parece ser bem baixa, situando-se na faixa de 10 a 10000 células por grama ou mililitro de produto consumido (Nascimento \& Stamford, 2000).

Cerca de 95\% dos coliformes existentes nas fezes humanas e de outros animais são E. coli, e dentre as bactérias de habitat reconhecidamente fecal, dentro do grupo dos coliformes fecais, a E. coli, embora também possa ser introduzida a partir de fontes não fecais, é o melhor indicador de contaminação fecal conhecido até o momento, pois satisfaz todas as exigências de um indicador ideal. Por esse motivo, as tendências atuais se direcionam no sentido da detecção específica de E. coli, com o desenvolvimento de diversos métodos que permitem a enumeração rápida dessa espécie diretamente (Silva et al., 2000). Sua presença nos alimentos tem um significado importante, pois revela as condições higiênico-sanitárias dos mesmos (Jakabi \& Franco, 1991). 


\subsection{Tratamentos térmicos utilizados no processamento do sorvete}

A utilização de tratamentos térmicos, geralmente sob a forma de calor úmido, constitui-se numa das técnicas mais empregadas visando assegurar a estabilidade microbiológica ou mesmo a esterilidade comercial dos alimentos (Roitman et al., 1988).

No caso do processamento do sorvete é utilizada a combinação de três tratamentos térmicos: pasteurização, refrigeração e congelamento.

\subsubsection{Pasteurização}

De acordo com Brasil (1996), todo estabelecimento que elaborar gelados comestíveis deverá apresentar condições higiênicas satisfatórias, atendendo os requisitos mínimos de higiene alimentar, bem como, todos os gelados comestíveis elaborados com produtos de laticínios ou ovos deverão ser obrigatoriamente pasteurizados.

A pasteurização além de obrigatória para os gelados comestíveis (Mosquim, 1999), é fundamental no processamento do sorvete pois torna a mistura substancialmente isenta de microrganismos vegetativos, eliminando todos os patógenos que possam estar nos ingredientes; coloca todos os sólidos em solução; auxilia na mistura derretendo a gordura e diminuindo a viscosidade; melhora o sabor da maioria das misturas; estende a manutenção da qualidade e melhora a uniformidade do produto (Marshall \& Arbuckle, 2000).

A utilização do leite pasteurizado ou fervido é essencial para assegurar a qualidade da mistura, garantindo um sorvete seguro microbiologicamente (Bryan et al., 1992).

Os mesmos autores ainda citam que, depois do tratamento térmico, é necessário certo cuidado com a mistura mantendo-a armazenada à baixa temperatura, garantindo assim uma baixa contagem bacteriana. 


\subsubsection{Refrigeração}

As baixas temperaturas são empregadas para retardar as reações químicas e a atividade das enzimas dos alimentos, bem como para retardar ou paralisa a multiplicação e a atividade dos microrganismos existentes nos mesmos (Frazier \& Westhoff, 1993).

Temperaturas mais baixas que a mínima para o microrganismo, inibirão seu crescimento, porém é possível que continue sua atividade metabólica a um ritmo mais lento. Por conseguinte, a refrigeração de um alimento a uma temperatura inferior a $7,2^{\circ} \mathrm{C}$, exerce uma influência distinta em diferentes microrganismos existentes nesse alimento (Frazier \& Westhoff, 1993).

Os mesmos autores afirmam que a maioria dos alimentos derivados de leite, podem ser mantidos em temperaturas de refrigeração $\left(5\right.$ a $\left.7,2^{\circ} \mathrm{C}\right)$ durante um tempo limitado sem que sua natureza original sofra modificações importantes, porém quanto mais baixa for a temperatura que se mantém os alimentos, maior é o custo da refrigeração. Citam também temperaturas mínimas de crescimento de algumas bactérias patógenas transmitidas pelos alimentos como a Escherichia coli com $4^{\circ} \mathrm{C}$, o Staphylococcus aureus com $10^{\circ} \mathrm{C}$ e a Salmonella com $5,2^{\circ} \mathrm{C}$.

\subsubsection{Congelamento}

O congelamento é uma medida de controle importante para prevenir o crescimento de bactérias em sorvetes. Conseqüentemente, deveria ser feito depois da preparação da mistura e mantido até o produto final ser armazenado (Bryan et al., 1992).

De acordo com Varnam \& Sutherland (1994), os microrganismos não são capazes de crescer em sorvetes se armazenados nas condições corretas, isto é, abaixo de $-18^{\circ} \mathrm{C}$; porém, podem sobreviver por muito tempo. Portanto, a contaminação microbiológica no sorvete, depende da eliminação das formas vegetativas dos patógenos por pasteurização e a prevenção da recontaminação no processamento, evitando com isso, o crescimento microbiológico antes da congelação. 
Frazier \& Westhoff (1993) afirmam que a carga microbiana dos ingredientes na produção do sorvete (leite, açúcar, entre outros) junto com a contaminação adquirida durante sua elaboração, determinará o número e as espécies de microrganismos existentes na mistura (calda) e a carga microbiana da mesma depois de haver sido pasteurizada e congelada.

Existem relatos de bactérias que cresceram a temperatura de $-10^{\circ} \mathrm{C}$ (Frazier \& Westhoff, 1993) no interior de sorvetes.

Os microrganismos têm a possibilidade de multiplicar-se abundantemente e de desenvolver uma atividade importante somente quando o descongelamento for muito lento ou quando o alimento for deixado a temperatura ambiente. As espécies de microrganismos que se multiplicam dependem da temperatura a que se realizou o descongelamento e do tempo que o alimento, uma vez descongelado, ficou exposto à temperatura ambiente (Frazier \& Westhoff, 1993).

Durante o armazenamento (antes da distribuição aos pontos de venda) os sorvetes deverão ser mantidos à temperatura de $-18^{\circ} \mathrm{C}$, e nos pontos de venda a temperatura deverá ser de, no máximo, $-5^{\circ} \mathrm{C}$ (Brasil, 1996).

\subsection{Efeito das temperaturas de congelação e refrigeração sobre os microrganismos}

Para se ter o efeito da congelação, é necessário saber antes o efeito da refrigeração sobre os microrganismos. Com isto, Frazier \& Westhoff (1993), resumem as fases de congelação nos microrganismos: esfriamento das células até $0^{\circ} \mathrm{C}$; esfriamento adicional com formação de cristais de gelo intracelulares e possivelmente extracelulares; concentração de solutos intracelulares e extracelulares; aumento do número de células em estado de congelação.

Apontam os mesmos autores que a congelação pode diminuir o número de microrganismos viáveis existentes no alimento, devido aos efeitos letais e subletais que exerce sobre eles, porém não é um procedimento de esterilização do alimento. Halász et al. (1982), afirmam que à medida que há o abaixamento da temperatura a partir da 
temperatura ótima de seu crescimento, a vida dos seres vivos torna-se mais difícil; o frio vai paralisando a sua atividade, até chegar um momento que cessa por completo.

Crê-se que os efeitos letais são devidos à desnaturação e precipitação das proteínas ou das enzimas indispensáveis para as células microbianas. Já os efeitos subletais estão relacionados a danos ou lesões nas células microbianas onde estes, impedem seu restabelecimento celular (Frazier \& Westhoff, 1993).

Carvalho et al. (1995), ressaltam que alguns constituintes do alimento podem aumentar ou reduzir a resistência da célula ao efeito do congelamento como por exemplo, a presença de íons, sais inorgânicos, acidez, agentes quelantes e certas enzimas que diminuem a resistência da bactéria ao processo de congelamento.

De acordo com Pinto et al. (2000), o efeito do congelamento sobre os microrganismos depende do $\mathrm{pH}$ e de outros parâmetros do meio, devido ao efeito interativo entre os vários fatores que afetam a capacidade de sobrevivência microbiana nos alimentos.

Como resposta dos microrganismos à congelação, existem muitas variáveis que influenciam no comportamento dos microrganismos. Entre elas estão a espécie e o estado do microrganismo; a velocidade e a temperatura de congelação; a duração do armazenamento congelado; o tipo de alimento; a influência da descongelação; descongelamentos sucessivos e os possíveis fenômenos que podem ocorrer durante o congelamento da célula (Frazier \& Westhoff, 1993). 


\section{MATERIAL E MÉTODOS}

\subsection{Origem e obtenção das amostras}

As amostras do leite e do sorvete de massa a base de leite foram obtidas em uma sorveteria artesanal da cidade de Piracicaba, interior do Estado de São Paulo. O leite analisado e utilizado no processamento foi o pasteurizado tipo $\mathrm{C}$, proveniente de um distribuidor local, o qual abastece semanalmente o estabelecimento. Este foi coletado em dois frascos erlenmeyer de 3L esterilizados e transportado em caixa isotérmica, preservando seu estado original. Os sorvetes foram processados e acondicionados em três embalagens totalizando aproximadamente $12 \mathrm{~L}$ de sorvete. As embalagens foram confeccionadas a base de cartão craft II revestidas com polipropileno de baixa densidade, específicas para este alimento. Os sorvetes foram transportados em caixas isotérmicas, sob gelo, para preservação de suas qualidades. Foram realizadas 12 coletas quinzenais, para o leite e para o sorvete sendo este último dividido em 2 sabores, sendo as coletas de 1 a 6 com sabor creme e as coletas de 7 a 12 com sabor chocolate, sabores esses de maior demanda na unidade produtora. As coletas foram realizadas durante os meses de setembro de 2003 a fevereiro de 2004, meses de maior demanda deste alimento. 


\subsection{Processamento do sorvete}

O Quadro 1 apresenta a formulação utilizada para o processamento do sorvete.

\begin{tabular}{|lc|}
\hline INGREDIENTE & QUANTIDADE \\
Leite “in natura” & $120 \mathrm{~L}$ \\
Leite em pó & $3,6 \mathrm{Kg}$ \\
Açúcar & $26,4 \mathrm{Kg}$ \\
Gordura vegetal & $4,4 \mathrm{Kg}$ \\
Liga neutra industrial & $360 \mathrm{~g}$ \\
\hline
\end{tabular}

Quadro 1 - Formulação para calda básica de sorvete de massa

Em cada processamento, foram utilizados $126 \mathrm{~L}$ de leite do tipo C, sendo feita a homogeneização e em seguida a retirada de $3 \mathrm{~L}$ em frascos esterilizados (Figura 1), para a realização das análises.

Após a homogeneização do leite no interior da pasteurizadora (Omega-Ice), foram adicionados os demais ingredientes como leite em pó, açúcar e gordura vegetal hidrogenada com aquecimento até $75^{\circ} \mathrm{C}$ por 15 minutos (Low Temperature Long Time LTLT), sempre sob agitação, com posterior resfriamento até $4^{\circ} \mathrm{C}$, conforme Figura 2. Após esse processo, a mistura foi transferida com o auxílio de frascos de aço inox, para a tina de maturação entre $4^{\circ} \mathrm{C}$ e $5^{\circ} \mathrm{C}$ sob constante agitação durante 24 horas, como mostra a Figura 3.

Com frascos plásticos graduados, foram transferidos 6L da mistura maturada para o batedor (modelo B5K45MG3) adicionando-se nesta fase o emulsificante (75-80g) e o pó sabor específico (20g/L para sabor creme e 50g/L para sabor chocolate), conforme Figura 4. Essa mistura foi então colocada em produtora horizontal descontínua (Imparfrio - modelo pHd), Figura 5, à temperatura de $-6^{\circ} \mathrm{C}$ para incorporação de ar (overrun) obtendo rendimento de aproximadamente $100 \%$, ou seja, o equivalente a $12 \mathrm{~L}$ de sorvete como mostra a Figura 6. 

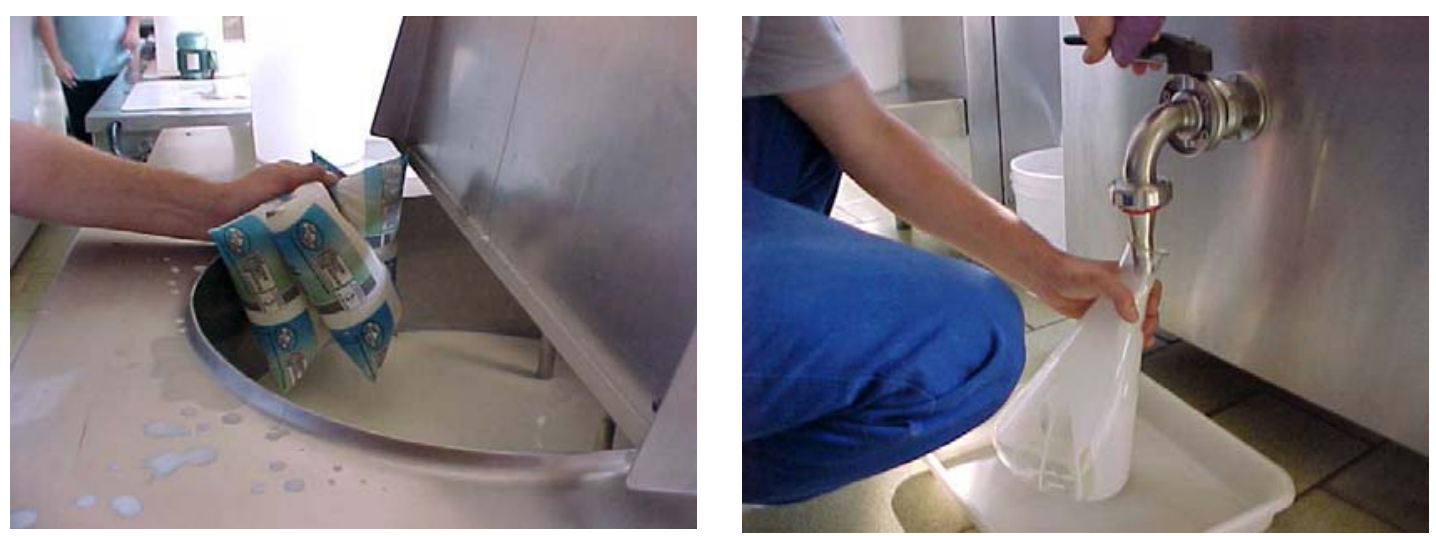

Figura 1 - Coleta do leite
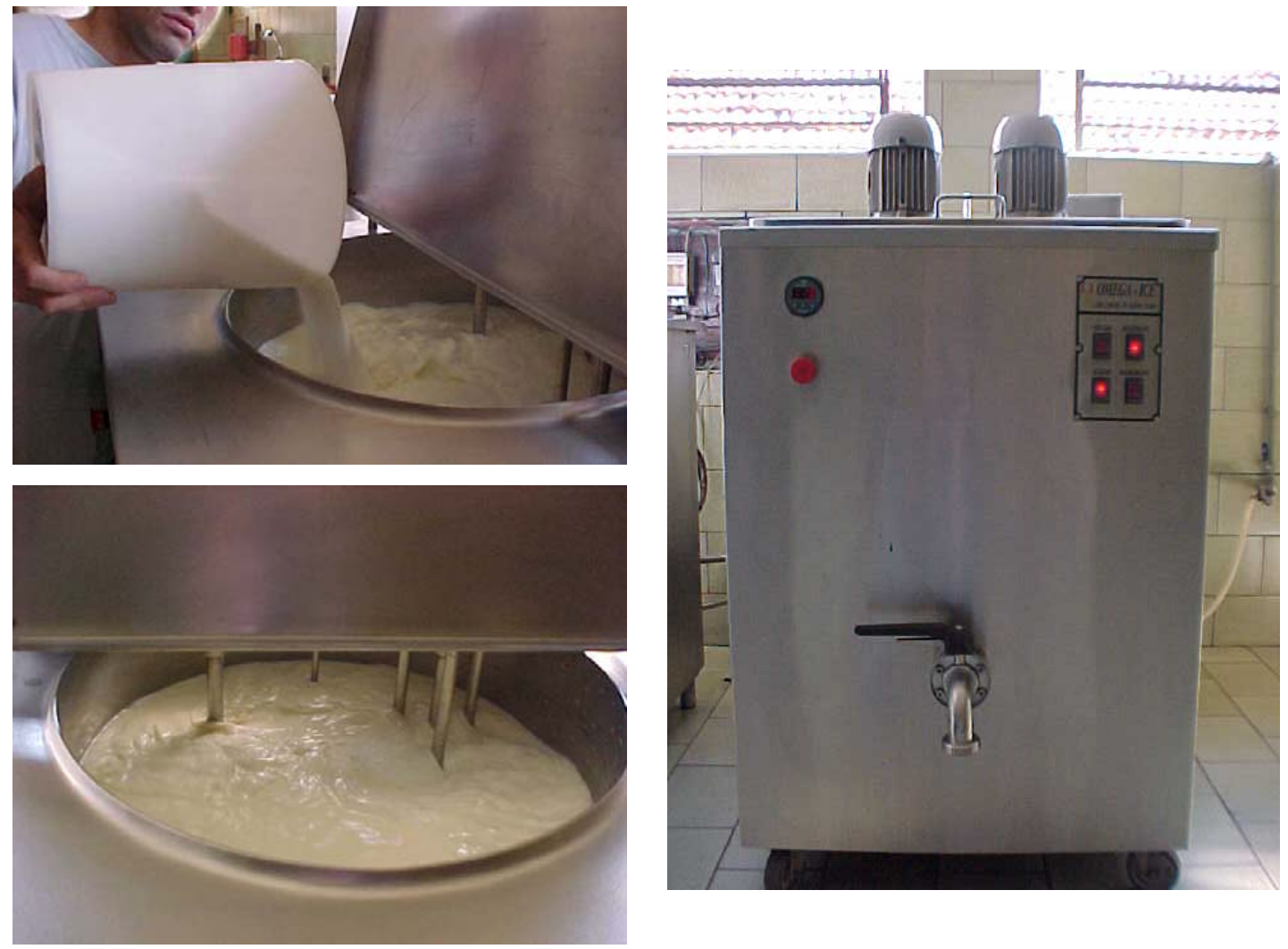

Figura 2 - Pasteurização dos ingredientes 


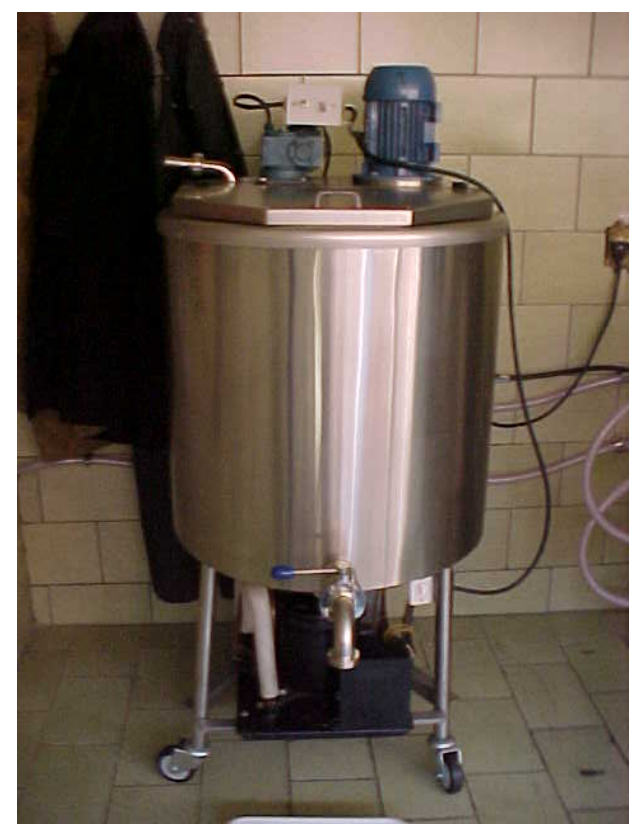

Figura 3 - Tina de Maturação
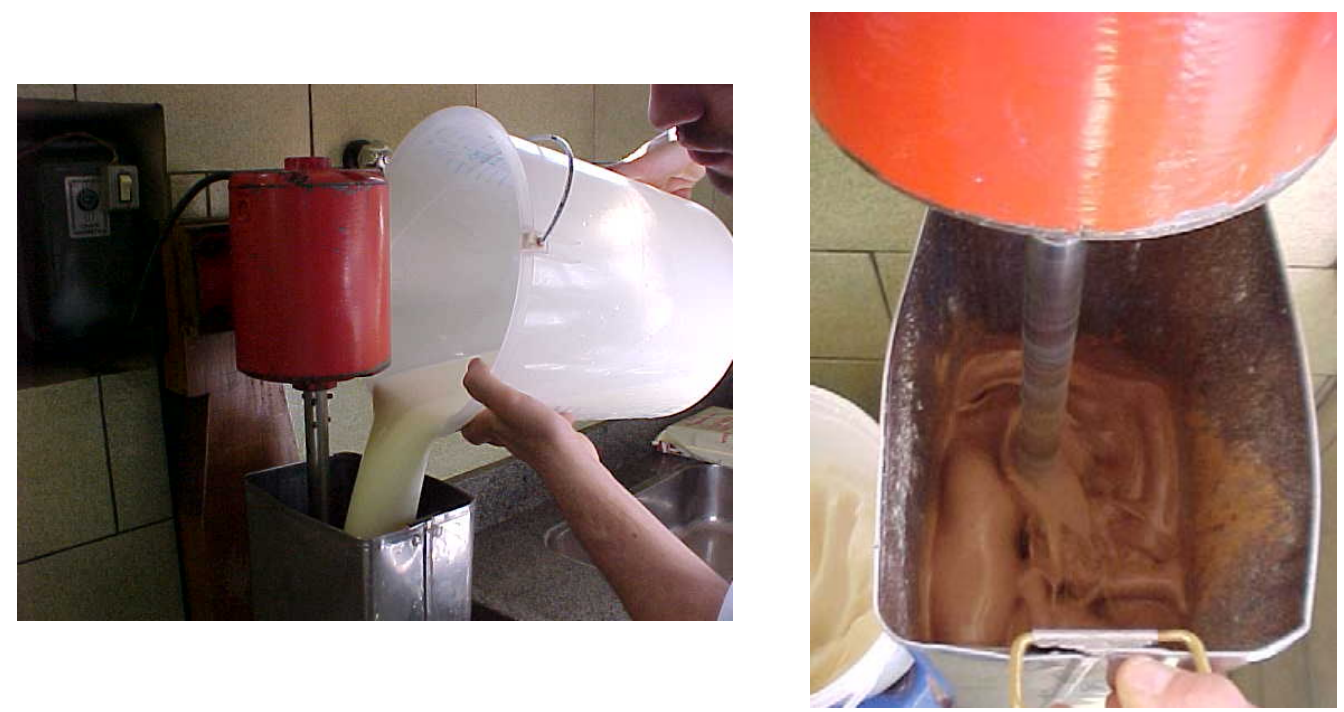

Figura 4 - Batedor 

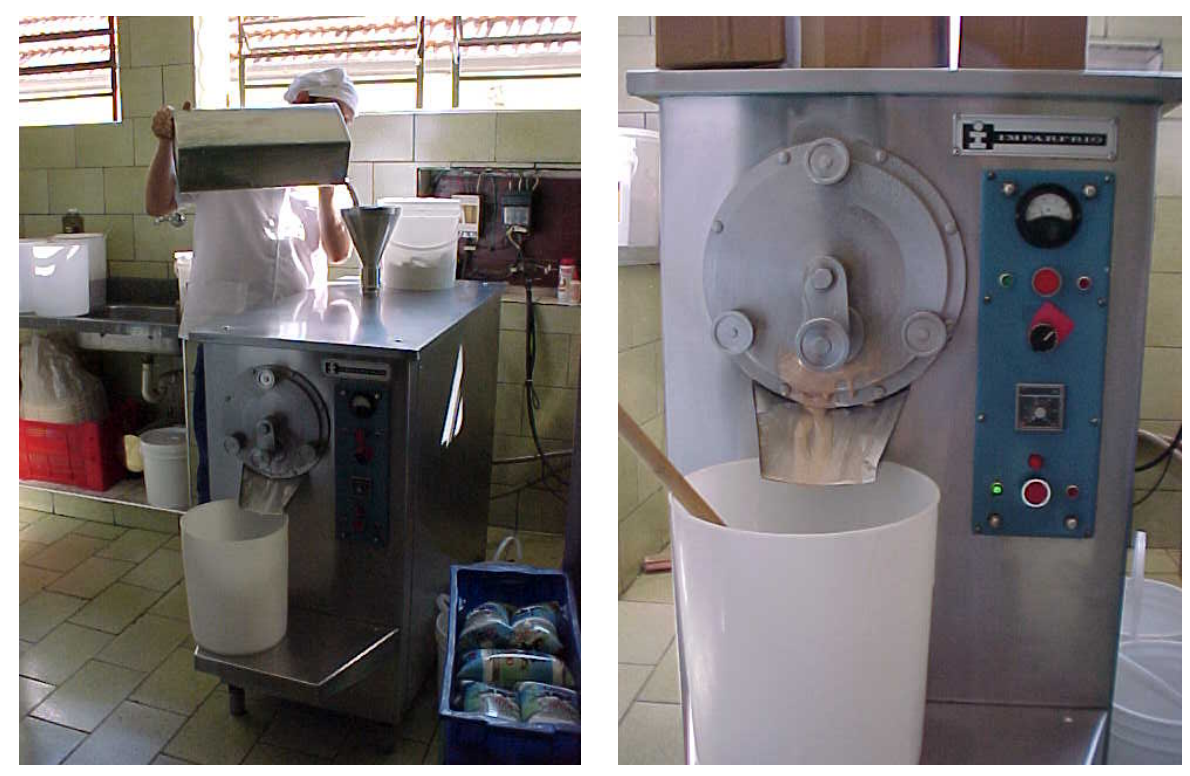

Figura 5 - Produtora horizontal
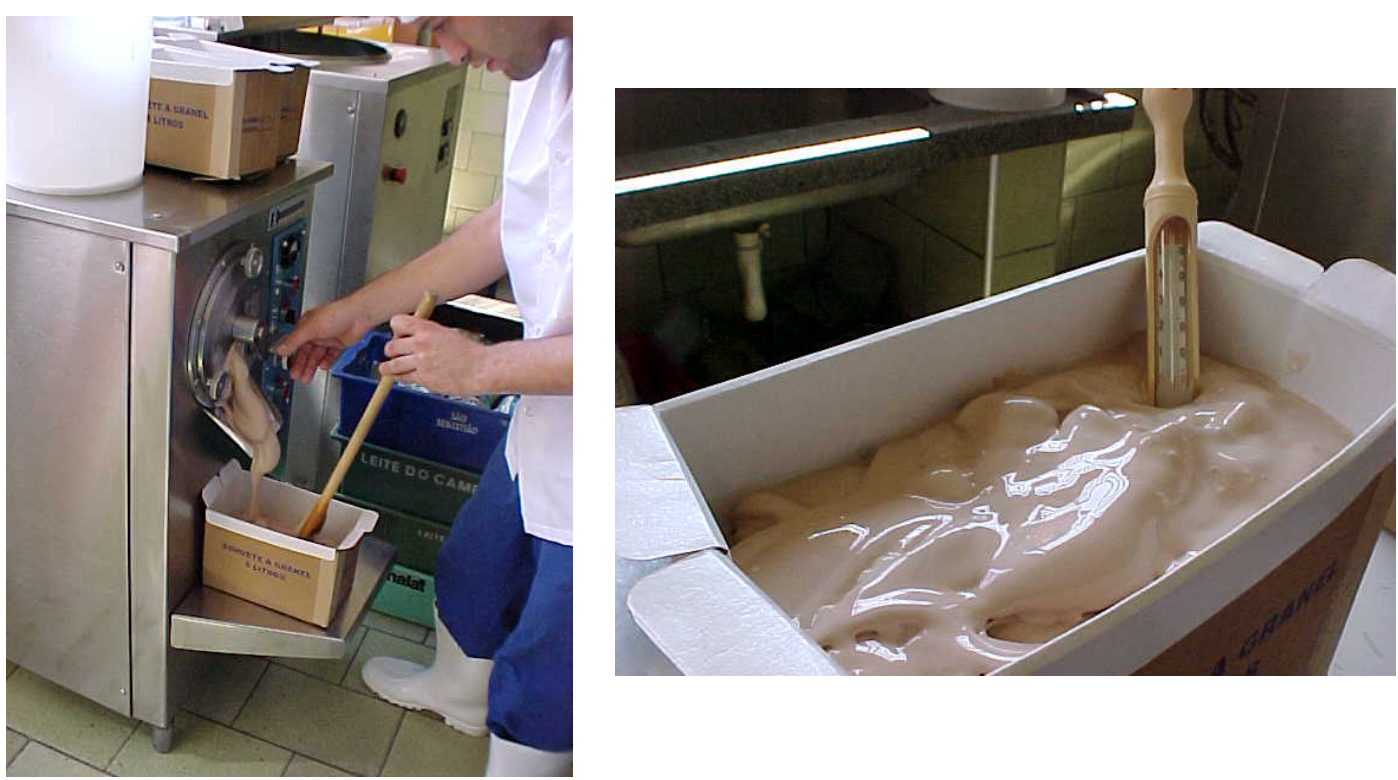

Figura 6 - Coleta dos sorvetes 
O processamento do sorvete foi conduzido conforme o fluxograma apresentado na Figura 7.

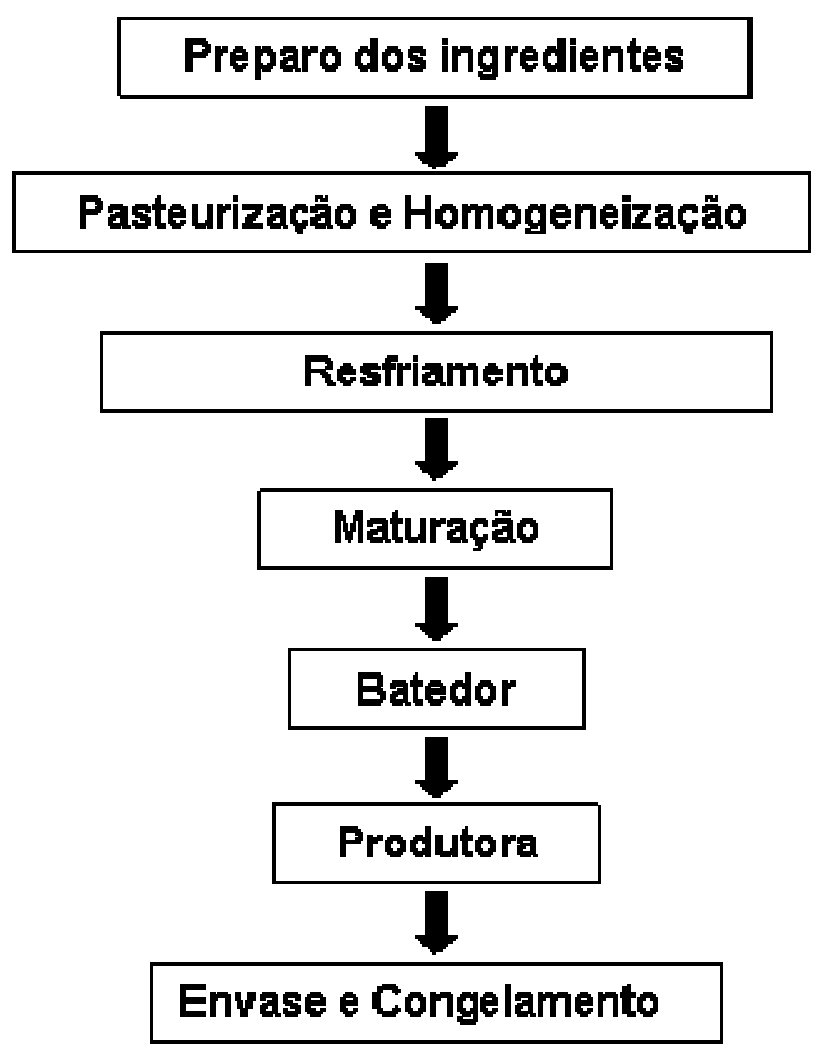

Figura 7 - Fluxograma do processamento do sorvete de massa

\subsection{Análises microbiológicas}

Foram realizadas as análises exigidas pela Resolução - RDC nº12, de 2 de janeiro de 2001 da Agência Nacional de Vigilância Sanitária - ANVISA (Brasil, 2001) para detecção de Salmonella, enumeração de Staphylococcus coagulase-positiva e coliformes fecais.

As amostras foram analisadas através das metodologias tradicionais/oficiais de acordo com os métodos padrões para produtos derivados de leite descritos por: Associação Brasileira de Normas Técnicas (ABNT), 1991; Vanderzant \& Splittstoesser, 1992 e Association of Official Analytical Chemists (AOAC), 2000. 


\subsection{Preparo das amostras}

As amostras do leite e do sorvete foram analisadas no Laboratório de Microbiologia do Departamento de Agroindústria, Alimentos e Nutrição da Escola Superior de Agricultura “Luiz de Queiroz” - ESALQ/USP na cidade de Piracicaba. As amostras foram analisadas imediatamente após o transporte, mantendo-as dentro das caixas isotérmicas durante a pesagem e retirada das alíquotas, para que não houvesse oscilação da temperatura de refrigeração, preservando assim o estado original das mesmas.

\subsubsection{Amostras de leite}

Para as análises de Staphylococcus coagulase-positiva e coliformes fecais fez-se as diluições das amostras. Para isso foram utilizados $20 \mathrm{~mL}$ de cada amostra do leite e colocados em frascos erlenmeyer previamente esterilizados, contendo $180 \mathrm{~mL}$ de água peptonada $0,1 \%$ esterilizada, obtendo-se assim a diluição $10^{-1}$. A partir dessa diluição, foram feitas diluições em série até a obtenção da diluição $10^{-4}$, sempre transferindo 10 mL de cada diluição para frascos esterilizados contendo $90 \mathrm{~mL}$ de água peptonada $0,1 \%$.

Para a análise de Salmonella, as amostras foram submetidas a um préenriquecimento, onde foram pipetados $25 \mathrm{~mL}$ de cada amostra de leite e transferidos para um erlenmeyer contendo $225 \mathrm{~mL}$ de Caldo Lactosado esterilizado.

\subsubsection{Amostras de sorvete}

Para as análises de Staphylococcus coagulase-positiva e coliformes fecais fez-se as diluições das amostras conforme citadas em 3.4.1, porém foram utilizados 20 g de cada amostra do sorvete.

Para a análise de detecção de Salmonella, o procedimento foi igual ao citado em 3.4.1, porém foram pesados 25 g de cada amostra de sorvete. 


\subsection{Microrganismos analisados}

\subsubsection{Número mais provável (NMP) de coliformes totais e fecais}

O Número Mais Provável (NMP) de coliformes totais e coliformes fecais foi determinado pelo método clássico de fermentação em tubos múltiplos, através da técnica dos tubos múltiplos de acordo com as recomendações da Associação Brasileira de Normas Técnicas (ABNT, 1991).

Essa técnica consta de duas fases distintas: o teste presuntivo, onde se busca a recuperação de células injuriadas e detecta a presença de microrganismos fermentadores da lactose, e o teste confirmativo, onde se determina a real população de coliformes totais e fecais.

No entanto, a norma da ABNT faz um ressalvo nessa técnica para produtos lácteos, onde a prova presuntiva não é efetuada, sendo as inoculações realizadas diretamente em séries de três tubos contendo caldo verde brilhante lactose bile $2 \%$ (CVBLB). Esse caldo de cultivo é bastante seletivo devido à presença de verde brilhante e sais biliares. Portanto, o caldo inibe o crescimento de microrganismos Gram positivos e oferece condições de desenvolvimento para microrganismos mais adaptados às condições gastrintestinais, favorecendo o crescimento de bactérias do grupo coliforme, que utilizam a lactose presente no caldo resultando na produção de gás.

Após a realização do teste confirmativo para coliformes totais (CVBLB a $35^{\circ} \mathrm{C} / 24-48 \mathrm{~h}$ ), foi realizado o teste confirmativo para coliformes fecais. As normas da ABNT recomendam que tal teste pode ser efetuado no mesmo caldo de cultivo (CVBLB) só que com incubação a $44,5^{\circ} \mathrm{C} / 24-48 \mathrm{~h}$. No presente trabalho, o teste confirmativo para coliformes fecais foi realizado simultaneamente em CVBLB e em caldo Escherichia coli (EC), ambos incubados a $44,5^{\circ} \mathrm{C}$ por $24-48 h$, para comparação da eficiência dos caldos na enumeração de coliformes fecais (Figura 8). 

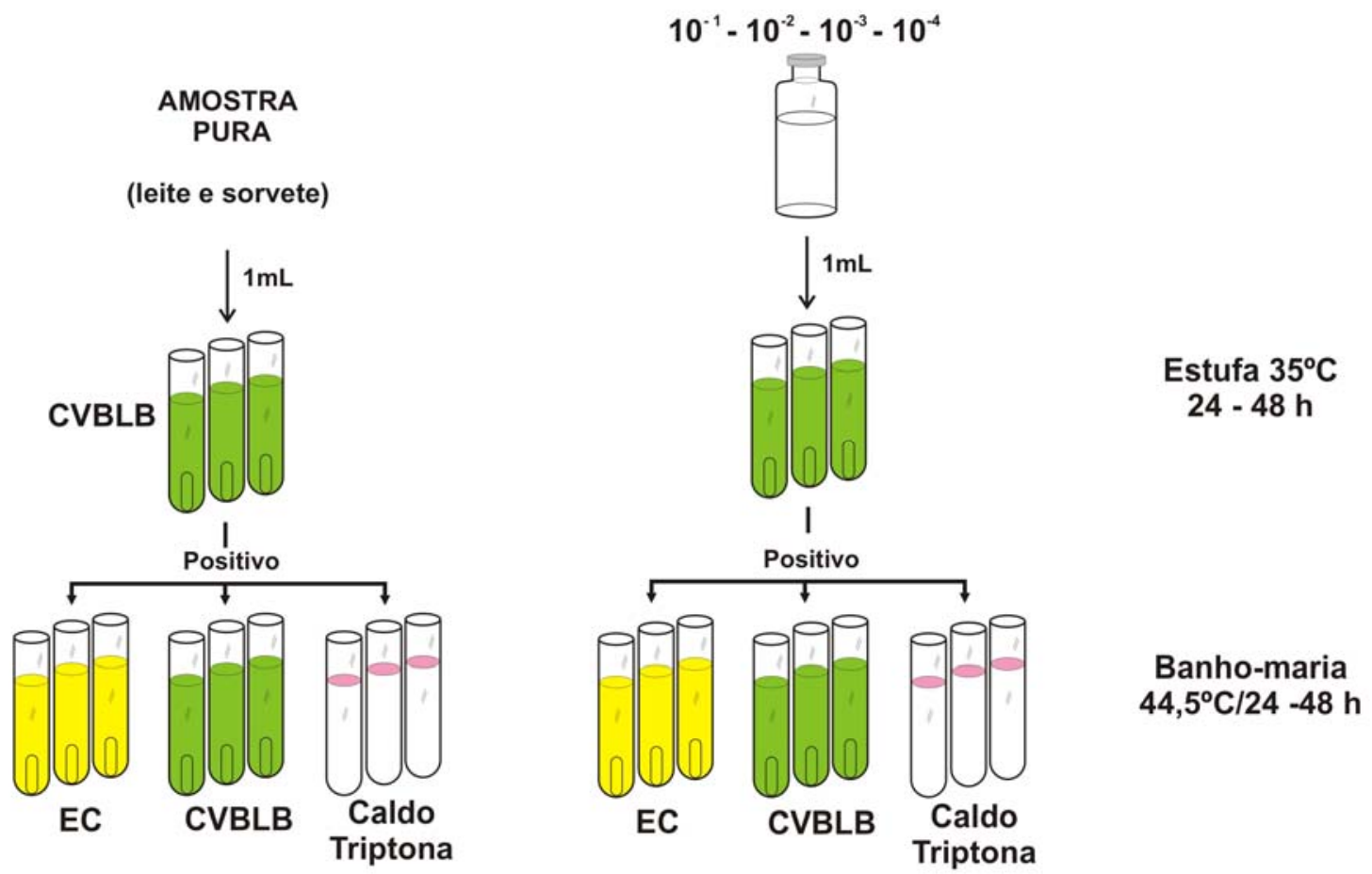

Figura 8 - Teste confirmativo para coliformes totais e fecais para a estimativa do NMP

Foram transferidas alíquotas de $1 \mathrm{~mL}$ das amostras sem diluição e das diluições $10^{-1}, 10^{-2}, 10^{-3}$ e $10^{-4}$ de leite e de sorvete para cinco séries de três tubos contendo CVBLB com tubos de Duhram, os quais foram incubados por $24-48$ horas a $35^{\circ} \mathrm{C}$ para o teste confirmativo, para coliformes totais.

Após a incubação dos mesmos, foram observados os tubos que apresentaram ou não produção de gás no interior dos tubos de Duhram. A partir dos tubos positivos para coliformes totais, inoculou-se, com o auxílio da alça níquel-cromo, tubos contendo o mesmo caldo (CVBLB) e tubos contendo caldo EC, ambos com tubo de Duhram; sendo também inoculados tubos contendo Caldo Triptona, todos incubados por 24-48 horas a $44,5^{\circ} \mathrm{C}$ em banho-maria.

Após 24 horas os tubos contendo Caldo Triptona foram submetidos à prova de produção de Indol, adicionando-se em cada tubo 0,2-0,3 mL do reativo de Kovac's. A presença de Indol foi detectada pela formação de um anel vermelho-escuro na superfície do líquido. 
Através dos tubos positivos contendo CVBLB, ou seja, daqueles que apresentaram turvação e produção de gás a $44,5^{\circ} \mathrm{C}$, foi possível determinar o NMP de coliformes fecais por $\mathrm{mL}$ de leite e por grama de sorvete. O mesmo princípio foi utilizado para os tubos contendo caldo EC incubados a $44,5^{\circ} \mathrm{C}$, os quais foram comparados com a metodologia aplicada para produtos lácteos recomendada pela ABNT.

A presença de coliformes fecais foi confirmada pela produção de indol no Caldo Triptona, além da produção de gás nos tubos com CVBLB e com caldo EC, uma vez que a temperatura $\left(44,5^{\circ} \mathrm{C}\right)$ e o período de incubação utilizados, impedem que outros microrganismos fermentem a lactose com produção de gás.

Mediante a consulta da tabela própria da ABNT, foi calculado o Número Mais Provável de coliformes totais e fecais por $\mathrm{mL}$ de leite e por grama de sorvete para cada amostra.

Os resultados obtidos foram comparados com os padrões vigentes no país para o leite e para o sorvete (Brasil, 2001).

\subsubsection{Presença/ausência de Salmonella spp.}

Para a detecção de Salmonella spp no leite e no sorvete, utilizou-se o kit "1-2 Test", da BioControl (Figura 9), método rápido qualitativo para a detecção das espécies móveis de Salmonella, aprovado e oficializado pela Association of Official Analytical Chemists (AOAC, 2000) para utilização em todos os tipos de alimentos e pelo Departamento de Inspeção de Produtos de Origem Animal - DIPOA (Brasil, 2002) para a detecção presuntiva da presença de Salmonella spp., em produtos de origem animal e água. 


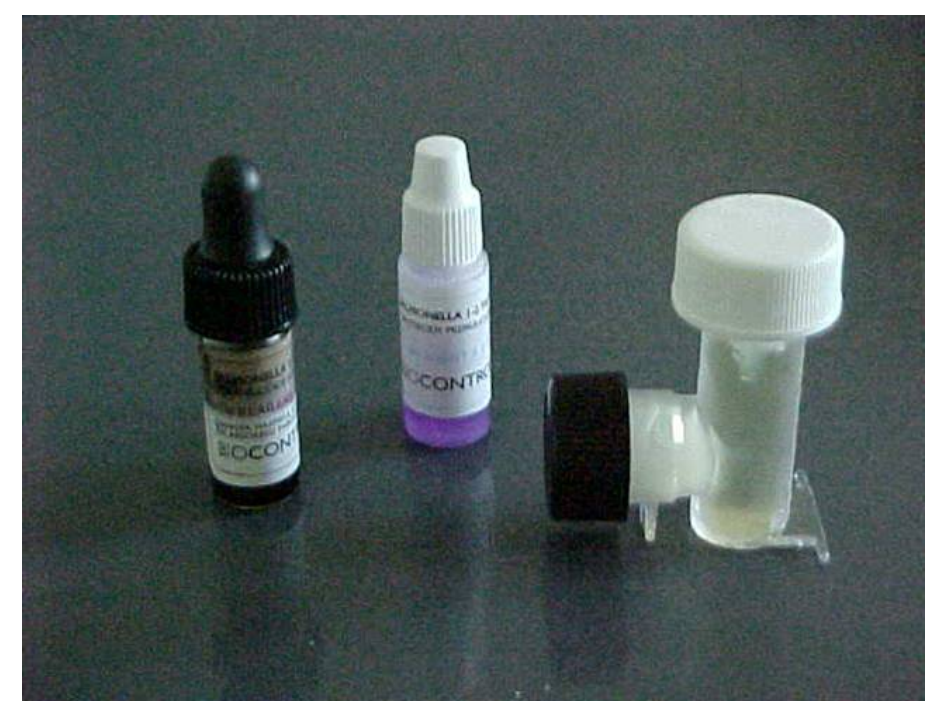

Figura 9 - Kit “1-2 Test” para Salmonella spp., da BioControl

O princípio se baseia na observação da imobilização da Salmonella pelos anticorpos polivalentes $\mathrm{H}$ (flagelar) contidos no meio de motilidade, com o desenvolvimento de uma banda visual bem definida (imunobanda).

A unidade de teste é composta por dois compartimentos: a câmara de inoculação, contendo Caldo Tetrationato-Verde Brilhante, e a câmara de motilidade, contendo um meio de motilidade não seletivo à base de peptona. A comunicação entre os compartimentos é vedada por um tampão, que deve ser removido antes da adição da amostra. Durante a incubação do kit inoculado, a Salmonella contida no Caldo Tetrationato-Verde Brilhante se move da câmara de inoculação para o meio de motilidade para reagir com os anticorpos formando a imunobanda.

Para o pré-enriquecimento, alíquotas de $25 \mathrm{~mL}$ de leite e de $25 \mathrm{~g}$ de sorvete foram transferidas para um erlenmeyer contendo $225 \mathrm{~mL}$ de Caldo Lactosado esterilizado e incubadas a $37^{\circ} \mathrm{C}$ por $24 \mathrm{~h}$. Para a análise, uma alíquota de $0,1 \mathrm{~mL}$ da amostra pré-enriquecida em Caldo Lactosado foi inoculada na câmara de inoculação. O "tip" presente na câmara de motilidade, o qual forma um vão no gel, foi retirado para a adição da solução de anticorpos. Os kits foram incubados a $35^{\circ} \mathrm{C}$ por $14-30$ horas. Após 
o período de incubação observou-se a formação ou não da imunobanda, a qual caracteriza a positividade do teste para o gênero Salmonella (Figura 10).

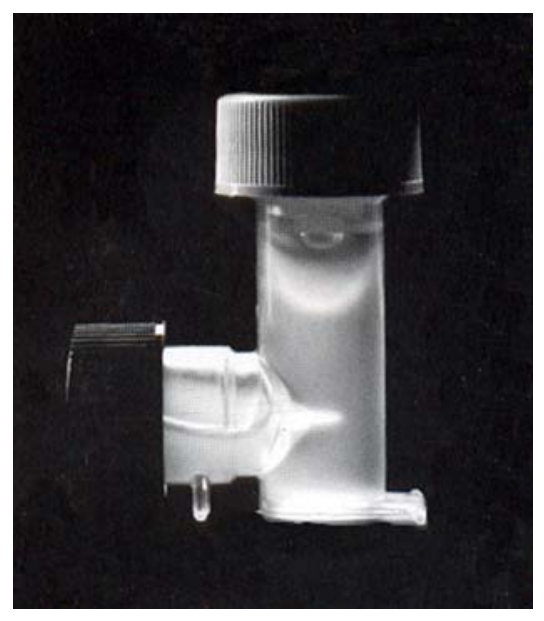

Figura 10 - Imunobanda característica de positividade para Salmonella

Os resultados obtidos foram comparados com a legislação vigente para o leite e para o sorvete (Brasil, 2001).

\subsubsection{Enumeração de Staphylococcus coagulase-positiva}

Para a contagem de Staphylococcus coagulase-positiva foi utilizado o método de contagem direta em placas, com semeadura em superfície e espalhamento com alça de Drigalsky descrito por Vanderzant \& Splittstoesser (1992).

Das diluições $10^{-1}$ e $10^{-2}$ preparadas previamente conforme o item 3.4, foram retiradas para cada amostra do leite e do sorvete, alíquotas de 0,3 +0,3 +0,4 mL totalizando $1 \mathrm{~mL}$ de $10^{-1}$, alíquotas de $0,1 \mathrm{~mL}$ de $10^{-1}$ e de $0,1 \mathrm{~mL}$ de $10^{-2}$, e inoculadas na superfície de placas de Petri contendo meio Ágar Baird-Parker (BPA), previamente preparadas. O inóculo foi espalhado com uma alça de Drigalsky. Após a secagem completa do inóculo, as placas foram invertidas e incubadas a $35-37^{\circ} \mathrm{C}$ por $24-48$ horas. 
Para a contagem presuntiva utilizaram-se todas as placas contendo 20 a 200 colônias e com o auxílio de um microscópio estereoscópico foram contadas as colônias típicas, ou seja, colônias pretas, circulares, pequenas, com bordas perfeitas, lisas, convexas e rodeadas por uma zona opaca e/ou um halo transparente. Além das colônias típicas, algumas que não preenchiam todos os requisitos mencionados também foram escolhidas para a realização da prova de produção de coagulase.

Para o teste de coagulase, retirou-se a colônia suspeita do meio BPA com o auxílio de uma alça níquel-cromo, inoculando-a em tubos de crescimento contendo $2 \mathrm{~mL}$ de Caldo Infusão de Cérebro e Coração (BHI), que foram incubados a temperatura de $35-37^{\circ} \mathrm{C}$ por 24 horas.

Após esse período, transferiu-se $0,2 \mathrm{~mL}$ da cultura formada para tubos com dimensões de 10 x 100 mm, estéreis e adicionou-se 0,5 mL de Coagu-Plasma (plasma de coelho) com EDTA, misturando-os somente com movimentos de rotação.

Conforme recomendações do fabricante, os tubos foram incubados a $37^{\circ} \mathrm{C}$ e observados a cada 30 minutos durante um intervalo de 4 horas (ou até um máximo de 24h), procurando a formação de um coágulo, que caracteriza a positividade da prova.

O cálculo da população de Staphylococcus coagulase-positiva foi realizado através da contagem em placas das colônias suspeitas e selecionadas, que apresentaram células em forma de cocos, Gram positivos e coagulação do plasma sanguíneo.

Os resultados foram comparados com os padrões vigentes da atual legislação brasileira (Brasil, 2001).

\subsection{Análise estatística}

Em vista dos objetivos e do delineamento experimental utilizado (casualizado em blocos), os testes utilizados foram: testes para dados pareados e coeficientes de correlação.

Primeiramente, os dados foram submetidos aos testes de adequação ao modelo linear e transformados por meio da função Log 10. Posteriormente, foram submetidos à análise de dados pareados, pelo PROC UNIVARIATE. 
Os coeficientes de correlação foram calculados utilizando-se o coeficiente de correlação de Spearman, objetivando a comparação das médias das análises para coliformes fecais através dos métodos empregados (caldo CVBLB e EC).

As análises foram efetuadas utilizando o programa estatístico Statistical Analysis System (SAS, 2001). 


\section{RESULTADOS E DISCUSSÃO}

\subsection{Coliformes totais e fecais}

Na Tabela 1, estão representados os NMP de coliformes totais presentes no leite e no sorvete. Nota-se que em cada coleta, foram analisadas 2 amostras para o leite e 3 amostras para o sorvete, todas com 3 repetições por amostra para a presença de coliformes totais.

Tabela 1. NMP de coliformes totais por $\mathrm{mL}$ de leite e por grama de sorvete ${ }^{1}$

\begin{tabular}{|c|c|c|c|c|c|c|c|}
\hline \multirow{2}{*}{ Análise } & \multicolumn{3}{|c|}{ Leite (NMP/mL) } & \multicolumn{4}{|c|}{ Sorvete (NMP/g) } \\
\hline & 1 & 2 & Média & 1 & 2 & 3 & Média \\
\hline $1^{\mathrm{a}}$ & $1,5 \times 10^{2}$ & $1,2 \times 10^{2}$ & $1,4 \times 10^{2}$ & $1,6 \times 10^{2}$ & $1,5 \times 10^{2}$ & $2,1 \times 10^{2}$ & $1,7 \times 10^{2}$ \\
\hline $2^{a}$ & $1,2 \times 10^{2}$ & $1,1 \times 10^{2}$ & $1,2 \times 10^{2}$ & $1,5 \times 10^{2}$ & $2,4 \times 10^{2}$ & $1,2 \times 10^{2}$ & $1,7 \times 10^{2}$ \\
\hline $3^{\mathrm{a}}$ & $4,6 \times 10^{2}$ & $2,9 \times 10^{2}$ & $3,8 \times 10^{2}$ & $2,4 \times 10^{2}$ & $2,1 \times 10^{2}$ & $2,1 \times 10^{2}$ & $2,2 \times 10^{2}$ \\
\hline $4^{\mathrm{a}}$ & $1,6 \times 10^{2}$ & $2,1 \times 10^{2}$ & $1,9 \times 10^{2}$ & $1,2 \times 10^{2}$ & $1,5 \times 10^{2}$ & $1,2 \times 10^{2}$ & $1,3 \times 10^{2}$ \\
\hline $5^{a}$ & $1,2 \times 10^{3}$ & $1,5 \times 10^{3}$ & $1,4 \times 10^{3}$ & $9,3 \times 10^{2}$ & $1,2 \times 10^{3}$ & $1,6 \times 10^{3}$ & $1,2 \times 10^{3}$ \\
\hline $6^{\mathrm{a}}$ & $1,1 \times 10^{2}$ & $1,1 \times 10^{2}$ & $1,1 \times 10^{2}$ & $9,3 \times 10$ & $1,1 \times 10^{2}$ & $9,5 \times 10$ & $9,9 \times 10$ \\
\hline $7^{\mathrm{a}}$ & $1,1 \times 10^{4}$ & $2,1 \times 10^{4}$ & $1,6 \times 10^{4}$ & $1,1 \times 10^{3}$ & $1,1 \times 10^{3}$ & $4,6 \times 10^{2}$ & $8,9 \times 10^{2}$ \\
\hline $8^{\mathrm{a}}$ & $1,5 \times 10^{3}$ & $2,3 \times 10^{2}$ & $8,7 \times 10^{2}$ & $1,1 \times 10^{4}$ & $9,3 \times 10^{3}$ & $1,5 \times 10^{3}$ & $7,3 \times 10^{3}$ \\
\hline $9^{a}$ & $1,1 \times 10^{3}$ & $9,3 \times 10^{3}$ & $5,2 \times 10^{3}$ & $1,1 \times 10^{3}$ & $2,1 \times 10^{3}$ & $3,9 \times 10^{3}$ & $2,4 \times 10^{3}$ \\
\hline $10^{\mathrm{a}}$ & $1,1 \times 10^{4}$ & $2,4 \times 10^{4}$ & $1,8 \times 10^{4}$ & $4,3 \times 10^{2}$ & $4,3 \times 10^{2}$ & $4,3 \times 10^{2}$ & $4,3 \times 10^{2}$ \\
\hline $11^{\mathrm{a}}$ & $2,9 \times 10^{4}$ & $2,4 \times 10^{4}$ & $2,7 \times 10^{4}$ & $4,6 \times 10^{3}$ & $1,1 \times 10^{4}$ & $2,4 \times 10^{3}$ & $6,0 \times 10^{3}$ \\
\hline $12^{\mathrm{a}}$ & $1,1 \times 10^{4}$ & $2,1 \times 10^{4}$ & $1,6 \times 10^{4}$ & $1,1 \times 10^{4}$ & $9,3 \times 10^{3}$ & $7,5 \times 10^{3}$ & $9,3 \times 10^{3}$ \\
\hline Média & $5,6 \times 10^{3}$ & $8,5 \times 10^{3}$ & $7,1 \times 10^{3}$ & $2,6 \times 10^{3}$ & $2,9 \times 10^{3}$ & $1,5 \times 10^{3}$ & $2,4 \times 10^{3}$ \\
\hline
\end{tabular}

${ }^{1}$ médias de 3 repetições 
Apesar de atualmente não existirem padrões para contagem de coliformes totais em leites pasteurizados e seus derivados no Brasil, para Bramley \& McKinnon (1990) contagens excedendo a $10^{2} / \mathrm{mL}$, evidenciam higiene insatisfatória na produção do leite.

Os autores Murph \& Boor (2000) consideram 50 NMP de coliformes/mL como indicativo de problema de higiene na produção do leite. Ainda, segundo a antiga Portaria da ANVISA (Brasil, 1997), para leite pasteurizado tipo C, havia uma tolerância de 10 NMP de coliformes totais/mL. Hoje a Resolução da ANVISA (Brasil, 2001) somente faz menção a tolerância de até $4 \mathrm{NMP}$ de coliformes a $45^{\circ} \mathrm{C} / \mathrm{mL}$ de leite pasteurizado.

As amostras de leite pasteurizado tipo $\mathrm{C}$ analisadas no presente trabalho e que foram coletadas momentos antes da sua utilização para a fabricação dos sorvetes, apresentaram valores de NMP de coliformes totais/mL variando de $1,1 \times 10^{2}$ a 2,9 x $10^{4}$ e com a média geral de 7,1 x $10^{3} \mathrm{NMP} / \mathrm{mL}$, ou seja, valores bastante superiores aos mencionados anteriormente, constituindo-se, com certeza num fator que deverá agir em detrimento da qualidade do produto final derivado, no caso sorvetes. Também nota-se provavelmente a falta de padronização em relação a obtenção, armazenamento, processamento térmico e distribuição do leite, uma vez que tal produto era sempre oriundo de um mesmo fornecedor e apresentou variações grandes $\left(10^{2}\right.$ a $\left.10^{4}\right)$ nas contagens de coliformes totais/mL. Todas as amostras de leite analisadas seriam enquadradas na categoria de “produto em condição higiênica insatisfatória”.

O leite tipo C beneficiado no Brasil, tem sido considerado um produto de baixa qualidade devido ao fato de normalmente ser proveniente de uma matéria-prima contaminada face às deficiências higiênico-sanitárias na sua produção. Porém, Barros et al. (1999) ao estudarem e analisarem 38 amostras de leite do tipo C provenientes de pequenas fazendas leiteiras, observaram que apenas 6 (16\%) apresentavam padrões microbiológicos inaceitáveis.

Em recente pesquisa, Freitas et al. (2002), ao analisarem 51 amostras de leite do tipo C, verificaram que 32,2\% excederam os padrões determinados pelo RIISPOA Brasil (1997), quanto ao NMP de coliformes totais. Semelhantes resultados foram encontrados por Tessari \& Cardoso (2002) em 50 amostras analisadas, das quais 36\% estavam acima do padrão estabelecido por Brasil (1997). 
Toda a matéria-prima animal no estado "in natura” utilizada para a fabricação de outros produtos alimentícios possue um certo número de microrganismos contaminantes. Assim, Halász et al. (1982) afirmam que dependendo das condições em que a matéria-prima (leite) for tratada, o número de microrganismos poderá aumentar durante o armazenamento e/ou processamento, tornando seus subprodutos inadequados para o consumo.

Quanto ao sorvete, por tratar-se de um alimento pasteurizado, os níveis de coliformes totais encontrados nas amostras analisadas foram elevados, apresentando uma média de 2,4 x $10^{3} \mathrm{NMP} / \mathrm{g}$ de sorvete. Isto pode ser indicativo de falhas no processamento, como manipulação incorreta nas operações de fabricação, equipamentos desregulados quanto as temperaturas necessárias exigidas, má sanitização dos equipamentos e/ou alta contaminação das matérias-primas.

Embora a legislação vigente (Brasil, 2001) não mencione limites de contaminação por coliformes totais para gelados comestíveis, a antiga Portaria da ANVISA (Brasil, 1997), estabelecia padrões microbiológicos para coliformes totais de no máximo $10^{2} \mathrm{NMP} / g$ de sorvete. Portanto, como a média encontrada na atual pesquisa foi de 2,4 x $10^{3}$ NMP de coliformes totais/g de sorvete, pode-se pensar em algumas hipóteses, como: matéria-prima muito contaminada, falhas e/ou condições higiênicas inadequadas no processamento ou armazenamento inadequado do produto. Nota-se que 94\% das amostras de sorvete analisadas excederam $10^{2}$ NMP de coliformes totais/g, que era o valor máximo tolerado por Brasil (1997), legislação que esteve em vigor até 2001.

Os resultados deste trabalho não diferiram daqueles obtidos por Hoffmann et al. (1995), Hoffmann et al. (2000), Pinto et al. (2000), Coelho (2001) e Richards et al. (2002), que constataram em todas as amostras de sorvetes analisadas, contagens acima de $10^{2}$ NMP de coliformes totais/g.

Quanto maior a população de bactérias coliformes, mais deficientes são as condições de higiene na fabricação, menor a durabilidade do produto e maiores os riscos à saúde dos consumidores. A enorme variação $\left(10\right.$ a $\left.10^{4}\right)$ nos níveis de contaminação por coliformes totais nas amostras de sorvetes analisadas, mostra falta de padronização no produto obtido, reflexo provavelmente de flutuações marcantes nas contaminações das 
matérias-primas utilizadas e/ou oscilações nos procedimentos utilizados na fabricação do sorvete, tanto em relação ao controle do processo, bem como na limpeza e sanificação dos equipamentos.

A Figura 11 mostra os valores médios de NMP de coliformes totais/mL de leite e por grama de sorvete.

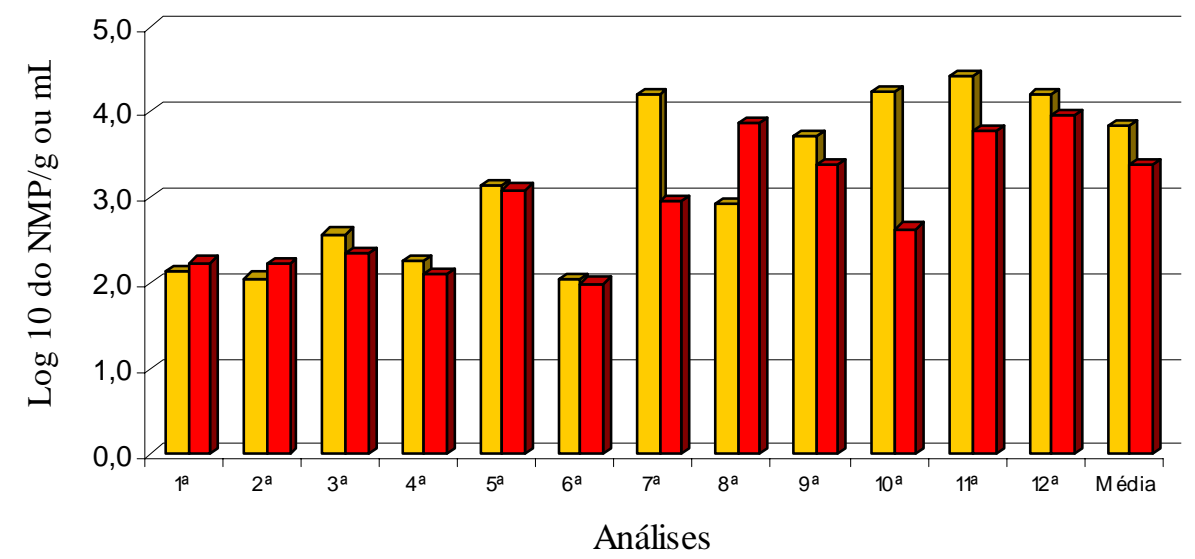

( $1^{\mathrm{a}}$ a $6^{\mathrm{a}}$ sabor creme e $7^{\mathrm{a}}$ a $12^{\mathrm{a}}$ sabor chocolate)

\section{$\square$ Leite $\quad \square$ Sorvete}

Figura 11 - Valores médios do NMP de coliformes totais no leite e no sorvete

Na Figura 11 pode-se observar a falta de padronização em relação as condições higiênicas das amostras, onde a partir da sétima análise tanto para o leite quanto para o sorvete de chocolate, a contaminação por coliformes totais aumentou substancialmente, chegando a elevar seus valores em até duas casas decimais. Tal fato pode ser um reflexo de uma matéria-prima de má qualidade onde, as amostras de sorvetes que apresentaram números mais elevados desses microrganismos, foram exatamente aquelas em que sua matéria-prima principal (leite) apresentava maiores números de contaminação.

Outro fator que pode ter influenciado no aumento da contaminação das amostras à partir da $7^{\mathrm{a}}$ análise foi o aumento da temperatura ambiente, por se tratar dos meses de verão, com temperaturas mais elevadas (dezembro, janeiro e fevereiro). 
De acordo com Guadagnoli (1992), a matéria-prima é um item importante a ser controlado para prevenir ou eliminar a possibilidade dos ingredientes virem a se tornar vetores de organismos ou resíduos potencialmente danosos; portanto, vigilância constante deve ser mantida sobre os mesmos. Para isso, é necessário ser rígido e seletivo com os fornecedores de materiais, garantindo uma qualidade constante.

O Instituto Nacional de Metrologia, Normalização e Qualidade Industrial (INMETRO) (1998), analisando 17 amostras de sorvetes de massa na cidade do Rio de Janeiro, encontrou em apenas 1 (5,9\%) marca, valores acima dos limites estabelecidos por Brasil (1997) para coliformes totais, sendo a mesma classificada como "produto em condição higiênica insatisfatória". Também analisando amostras de sorvete a base de leite, Pinto et al. (2000) detectaram valores de coliformes totais/g, acima dos referidos por Brasil (1997), em 83,3\% das amostras analisadas.

Das amostras de sorvetes analisadas na presente pesquisa, apenas $2(5,6 \%)$ das 36, estariam de acordo com os padrões estabelecidos pelo referido padrão.

Bryan et al. (1992), analisando amostras de sorvete, encontraram valores para coliformes totais acima da média encontrada na presente pesquisa, com variações entre $10^{4}$ e $10^{7} \mathrm{NMP} / \mathrm{g}$ de sorvete. Como hipóteses para esses valores elevados encontrados, os autores citam contaminações: nos ingredientes, na preparação das misturas e depois da preparação. Também na pesquisa de Falcão et al. (1983), 66,6\% das amostras de sorvetes analisadas apresentaram valores acima de $10^{2} \mathrm{NMP}$ de coliformes totais/g de sorvete.

A Tabela 2 ilustra os valores de NMP de coliformes fecais encontrados nas amostras de leite analisadas. Aqui, como em cada coleta, 2 amostras foram analisadas utilizando-se o CVBLB e 2 amostras utilizando-se o caldo EC, o total de amostras de leite analisadas para coliformes fecais foi de 48 . 
Tabela 2. NMP de coliformes fecais por $\mathrm{mL}$ de leite ${ }^{1}$, em caldo EC e em CVBLB, incubados a $44,5^{\circ} \mathrm{C} / 24-48 \mathrm{~h}$

\begin{tabular}{|c|c|c|c|c|c|c|}
\hline Análise & \multicolumn{3}{|c|}{ Caldo VBLB } & \multicolumn{3}{|c|}{ Caldo EC } \\
\hline & Leite 1 & Leite 2 & Média & Leite 1 & Leite 2 & Média \\
\hline $1^{\mathrm{a}}$ & 0,36 & 0,36 & 0,36 & 4,3 & 2 & 3,2 \\
\hline $2^{a}$ & $<0,3$ & $<0,3$ & $<0,3$ & 0,36 & $<0,3$ & 0,3 \\
\hline $3^{a}$ & $<0,3$ & $<0,3$ & $<0,3$ & 2,3 & $<0,3$ & 2,3 \\
\hline $4^{\mathrm{a}}$ & $<0,3$ & $<0,3$ & $<0,3$ & $<0,3$ & 2 & 1,1 \\
\hline $5^{a}$ & 2,3 & 0,36 & 1,3 & $1,1 \times 10^{2}$ & $4,6 \times 10$ & $7,8 \times 10$ \\
\hline $6^{a}$ & $1,1 \times 10^{2}$ & $2,1 \times 10$ & $6,5 \times 10$ & 4,2 & 5,3 & 4,8 \\
\hline $7^{\mathrm{a}}$ & $4,6 \times 10^{2}$ & $2,0 \times 10$ & $2,4 \times 10^{2}$ & $1,1 \times 10^{3}$ & $9,3 \times 10^{2}$ & $1,0 \times 10^{3}$ \\
\hline $8^{a}$ & $3,6 \times 10$ & $9,1 \times 10$ & $6,3 \times 10$ & $9,1 \times 10$ & $1,1 \times 10^{2}$ & $1,0 \times 10^{2}$ \\
\hline $9^{a}$ & $2,3 \times 10$ & $2,9 \times 10$ & $2,6 \times 10$ & $2,3 \times 10$ & $3,9 \times 10$ & $3,1 \times 10$ \\
\hline $10^{\mathrm{a}}$ & $3,6 \times 10$ & $1,6 \times 10$ & $2,6 \times 10$ & $3,6 \times 10$ & $1,2 \times 10$ & $2,4 \times 10$ \\
\hline $11^{\mathrm{a}}$ & $9,1 \times 10$ & $2,0 \times 10^{2}$ & $1,4 \times 10^{2}$ & $9,3 \times 10^{2}$ & $4,6 \times 10^{2}$ & $6,9 \times 10^{2}$ \\
\hline $12^{\mathrm{a}}$ & $2,4 \times 10$ & $2,1 \times 10$ & $2,2 \times 10$ & $4,4 \times 10^{2}$ & $9,1 \times 10$ & $2,6 \times 10^{2}$ \\
\hline Média & $6,5 \times 10$ & $3,3 \times 10$ & $4,9 \times 10$ & $2,3 \times 10^{2}$ & $1,4 \times 10^{2}$ & $1,8 \times 10^{2}$ \\
\hline
\end{tabular}

${ }^{1}$ médias de 3 repetições

Convém salientar que a menção de contagem $<0,3$ para a metodologia de tubos múltiplos utilizada, significa que nenhum dos tubos inoculados se mostrou positivo, podendo ser encarada como ausência de coliformes fecais/mL em leite.

O padrão microbiológico estabelecido pela atual legislação, Brasil (2001) para tolerância de coliformes a $45^{\circ} \mathrm{C}$ é de $4 \mathrm{NMP} / \mathrm{mL}$ em leite pasteurizado.

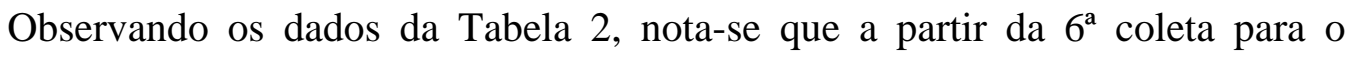
CVBLB e da $5^{\text {a }}$ coleta para o caldo EC, todas as amostras de leite analisadas, apresentaram valores de coliformes a $45^{\circ} \mathrm{C}$ superiores aos tolerados pela legislação, Brasil (2001). 
A Figura 12 apresenta os valores médios de coliformes fecais - Log 10 do $\mathrm{NMP} / \mathrm{mL}$ de leite, tanto no CVBLB como no caldo EC, incubados a $44,5^{\circ} \mathrm{C} / 24-48 \mathrm{~h}$.

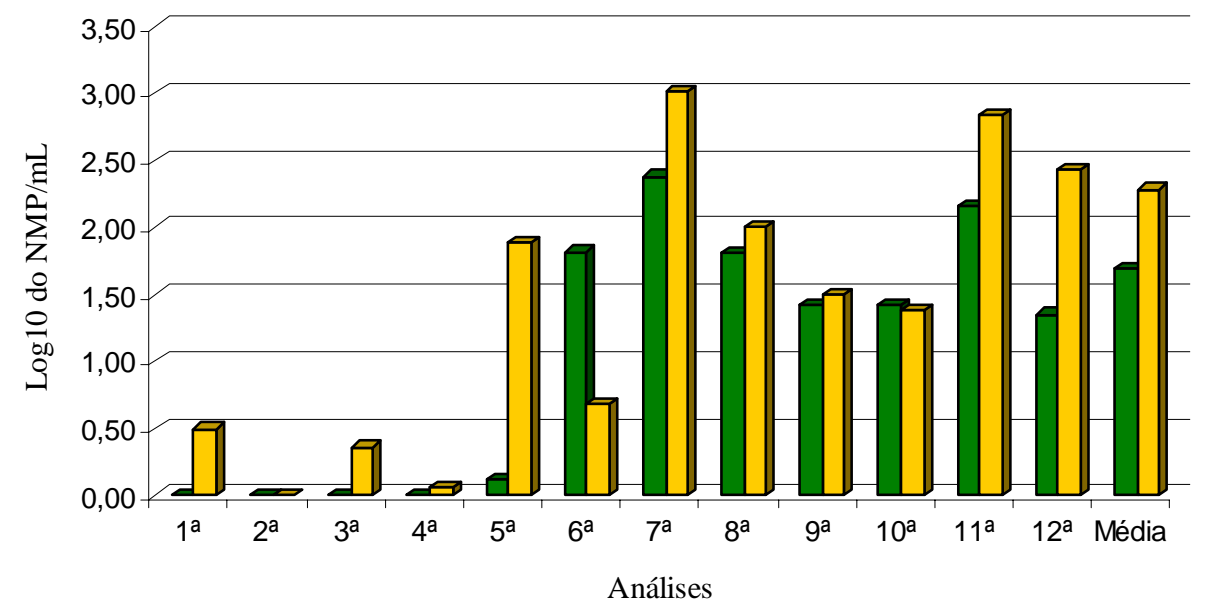

$\square$ CVBLB $\square$ caldo EC

Figura 12 - Valores médios de coliformes fecais no leite utilizando o CVBLB e o caldo EC

Das 24 amostras de leite analisadas, 14 (58,3\%) apresentaram valores de coliformes a $45^{\circ} \mathrm{C}$ superiores aos tolerados pelo referido padrão, quando o teste foi conduzido utilizando o CVBLB (Figura 13) e 17 (70,8\%) apresentaram também valores de coliformes a $45^{\circ} \mathrm{C}$ superiores aos referidos como limite máximo pela legislação, Brasil (2001), quando o caldo utilizado para o teste foi o caldo EC (Figura 14). 


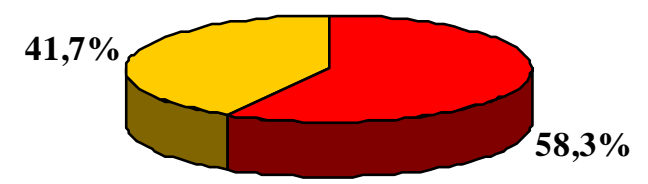

Acima dos padrões $\square$ De acordo com os padrões

Figura 13 - Porcentagem de coliformes fecais no leite utilizando o CVBLB

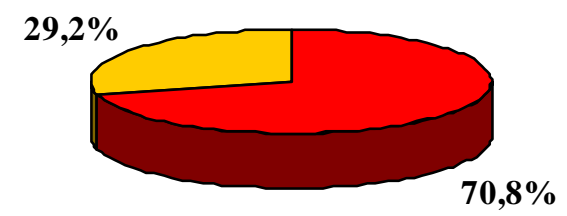

$\square$ Acima dos padrões $\square$ De acordo comos padrões

Figura 14 - Porcentagem de coliformes fecais no leite utilizando o caldo EC

Quanto à variação nas estimativas do NMP de coliformes a $45^{\circ} \mathrm{C} / \mathrm{mL}$ de leite, nota-se pelos valores da Tabela 2, bem como pela representação gráfica nas Figuras 12, 13 e 14, que os valores encontrados quando o caldo utilizado foi o EC foram normalmente maiores do que quando se utilizou o CVBLB. Embora a ABNT (1991) sugira a utilização do CVBLB para a confirmação de coliformes fecais, o que facilita muito o trabalho, já que um só caldo pode ser utilizado tanto para o teste confirmativo de coliformes totais como para o teste confirmativo para coliformes a $45^{\circ} \mathrm{C}$ (fecais), pelos dados da presente pesquisa, seria mais recomendável a utilização do caldo EC para coliformes a $45^{\circ} \mathrm{C}$. Tal recomendação se justifica pelo fato de ter havido diferença significativa $(\mathrm{p}<0,05)$ entre os caldos utilizados.

Uma segunda linha de análise dos dados partiu dos cálculos dos coeficientes de correlação entre os caldos utilizados. Segundo Hatcher \& Stepansky (1994) para dados 
normalmente distribuídos deve-se calcular o coeficiente de correlação de Pearson. Se a suposição de normalidade não é razoável deve-se preferir o coeficiente de correlação de Spearman.

O coeficiente de correlação de Spearman entre os caldos EC e CVBLB foi de 0,75. Portanto, mesmo os caldos tendo apresentado diferença estatística significativa $(\mathrm{p}<0,05)$, eles se correlacionaram em $75 \%$ das amostras de leite analisadas na presente pesquisa na recuperação dos coliformes fecais.

Ainda, quando analisadas caso a caso as amostras, nota-se que 3 (12,5\%) amostras que se mostraram de acordo com o padrão da ANVISA, Brasil (2001), quando se utilizou o CVBLB, se mostraram fora do referido padrão, quando o caldo utilizado foi o caldo EC. O inverso não ocorreu, mostrando que a recuperação de coliformes fecais em caldo EC é melhor do que em CVBLB.

Tessari \& Cardoso (2002), ao analisarem amostras de leite pasteurizado, encontraram apenas 18\% das amostras com valores acima dos padrões legais. Tinôco et al. (2002), também trabalhando com amostras de leite pasteurizado, encontraram 45\% das mesmas em desacordo com os padrões estabelecidos. Ambas as pesquisas, portanto, encontraram valores de contaminação do leite pasteurizado, por coliformes a $45^{\circ} \mathrm{C}$, inferiores aos encontrados no presente trabalho.

De acordo com Bryan et al. (1992), o leite pasteurizado é essencial para assegurar a qualidade da mistura, garantindo um sorvete seguro microbiologicamente, porém a alta incidência de coliformes a $45^{\circ} \mathrm{C}$ (fecais) encontrada nas amostras de leite pasteurizado tipo $\mathrm{C}$ analisadas na presente pesquisa, colocando tais amostras em condições higiênico-sanitárias insatisfatórias, é um fator preocupante e provavelmente de grande importância no comprometimento da boa qualidade microbiológica do sorvete derivado. Também preocupante na presente pesquisa é o fato de oscilações marcantes na qualidade microbiológica do leite que era sempre do mesmo fornecedor, deixando clara a dificuldade de padronização e, portanto, de garantia de qualidade.

A Tabela 3 apresenta as estimativas do NMP de coliformes fecais /g de sorvete. Como em cada coleta 3 amostras de sorvete foram analisadas para coliformes fecais 
utilizando-se o CVBLB e 3 utilizando-se o caldo EC, o total de amostras de sorvete analisadas foi de 72 .

Tabela 3. NMP dos coliformes fecais/g de sorvete ${ }^{1}$, em CVBLB e em caldo E.C

\begin{tabular}{ccccccccc}
\hline Análise & \multicolumn{9}{c}{ CVBLB } & \multicolumn{5}{c}{ Caldo EC } \\
\cline { 2 - 9 } & 1 & 2 & 3 & Média & 1 & 2 & 3 & Média \\
\hline $1^{\mathrm{a}}$ & $<0,3$ & $<0,3$ & $<0,3$ & $<0,3$ & 2,1 & 1,5 & 1,5 & 1,7 \\
$2^{\mathrm{a}}$ & $<0,3$ & $<0,3$ & $<0,3$ & $<0,3$ & $<0,3$ & $<0,3$ & $<0,3$ & $<0,3$ \\
$3^{\mathrm{a}}$ & $<0,3$ & $<0,3$ & 0,36 & 0,31 & 0,36 & $<0,3$ & $<0,3$ & 0,31 \\
$4^{\mathrm{a}}$ & $<0,3$ & $<0,3$ & 0,36 & 0,31 & 2 & 1,1 & 1,2 & 1,43 \\
$5^{\mathrm{a}}$ & $<0,3$ & $<0,3$ & $<0,3$ & $<0,3$ & $2,1 \times 10$ & $2,9 \times 10$ & $4,6 \times 10$ & $3,2 \times 10$ \\
$6^{\mathrm{a}}$ & $1,1 \times 10^{2}$ & 5,3 & 3,4 & $3,9 \times 10$ & 3,5 & 3,4 & 2,7 & 3,2 \\
$7^{\mathrm{a}}$ & $3,0 \times 10$ & $3,0 \times 10$ & $2,3 \times 10$ & $2,8 \times 10$ & $2,1 \times 10^{2}$ & $4,3 \times 10$ & $4,6 \times 10$ & $9,9 \times 10$ \\
$8^{\mathrm{a}}$ & $2,9 \times 10$ & $2,4 \times 10$ & $2,1 \times 10$ & $2,5 \times 10$ & $4,3 \times 10^{2}$ & $3,0 \times 10$ & $1,1 \times 10^{2}$ & $1,9 \times 10^{2}$ \\
$9^{\mathrm{a}}$ & $3,0 \times 10^{2}$ & $2,1 \times 10^{2}$ & $1,6 \times 10^{2}$ & $2,2 \times 10^{2}$ & $3,0 \times 10^{2}$ & $2,3 \times 10^{2}$ & $1,1 \times 10^{2}$ & $2,1 \times 10^{2}$ \\
$10^{\mathrm{a}}$ & $2,9 \times 10$ & $2,1 \times 10$ & $2,4 \times 10$ & $2,5 \times 10$ & $2,9 \times 10$ & $2,3 \times 10$ & $3,6 \times 10$ & $2,9 \times 10$ \\
$11^{\mathrm{a}}$ & $7,3 \times 10$ & $9,1 \times 10$ & $3,0 \times 10$ & $6,5 \times 10$ & $4,3 \times 10^{2}$ & $1,5 \times 10^{2}$ & $3,6 \times 10$ & $2,0 \times 10^{2}$ \\
$12^{\mathrm{a}}$ & $2,9 \times 10$ & $3,0 \times 10$ & $9,3 \times 10^{2}$ & $3,3 \times 10^{2}$ & $2,9 \times 10^{2}$ & $7,3 \times 10$ & $2,8 \times 10^{2}$ & $2,1 \times 10^{2}$ \\
Média & $5,0 \times 10$ & $3,4 \times 10$ & $9,9 \times 10$ & $6,1 \times 10$ & $1,4 \times 10^{2}$ & $4,9 \times 10$ & $5,6 \times 10$ & $8,3 \times 10$ \\
\hline
\end{tabular}

${ }^{1}$ médias de 3 repetições

Da mesma forma como foi comentado para os valores de NMP de coliformes fecais para as amostras de leite analisadas, aqui também a menção de contagem $<0,3$, significa que nenhum dos tubos inoculados se mostrou positivo, podendo ser considerada como ausência de coliformes fecais/g de sorvete.

O padrão microbiológico para gelados comestíveis, estabelecidos pela atual legislação da ANVISA (Brasil, 2001) para coliformes a $45^{\circ} \mathrm{C}$ é de 5 x 10 NMP/g.

Os valores encontrados na Tabela 3 para o sorvete de creme ( $1^{\mathrm{a}}$ a $6^{\mathrm{a}}$ análises) estão de acordo com os padrões estabelecidos pelo referido padrão utilizando-se ambos os caldos, CVBLB e EC, tendo apenas uma das amostras em CVBLB ultrapassado esse limite.

Para o sorvete de chocolate ( $7^{\mathrm{a}}$ a $12^{\mathrm{a}}$ análises), os valores encontrados excederam o padrão estabelecido pela referida legislação em 6 amostras (33,3\%) em CVBLB e em 11 amostras (61,1\%) em caldo EC, valores esses mais ou menos esperados devido a alta contaminação de sua principal matéria-prima (o leite) já analisada 
anteriormente. Aqui também como já havia sido constatado nas análises das amostras de leite, os NMP de coliformes fecais/g de sorvete encontrados quando se utilizou o caldo EC foram maiores do que quando se utilizou o CVBLB.

A Figura 15 mostra os valores médios encontrados como NMP de coliformes fecais/g de sorvete.

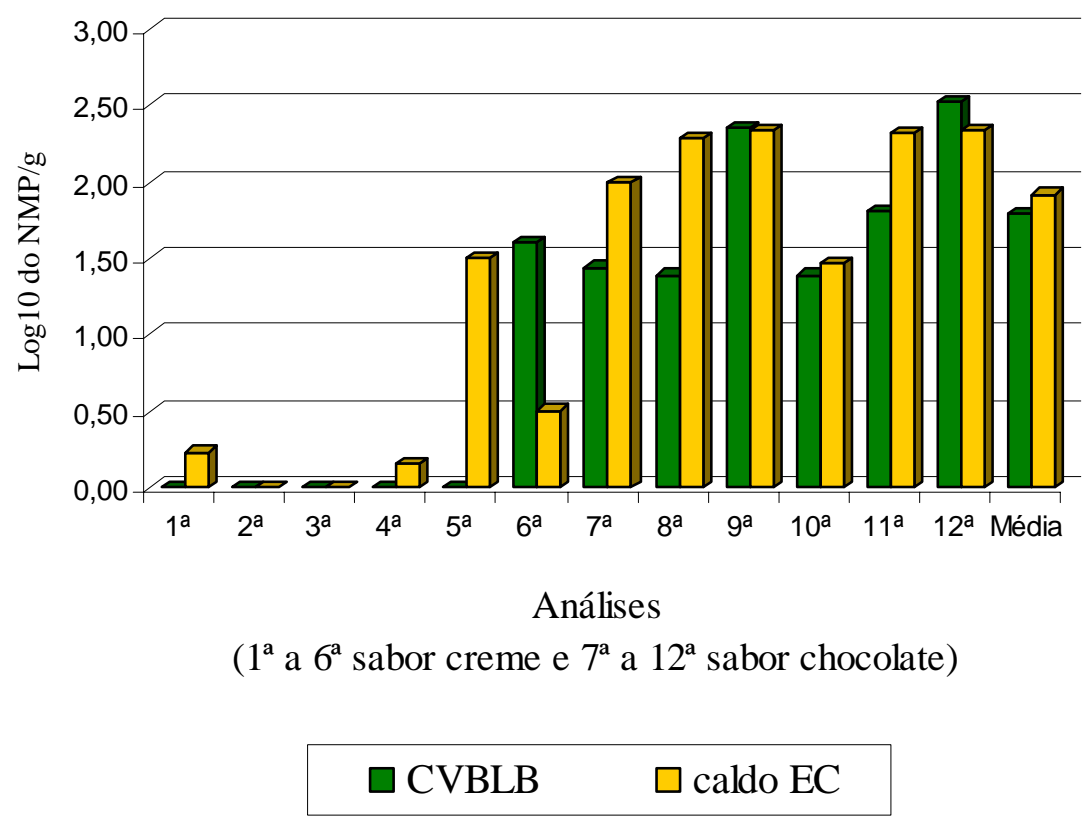

Figura 15 - Valores médios de coliformes fecais no sorvete utilizando o CVBLB e o caldo EC

Na Figura 15 notam-se valores mais elevados de contaminação por coliformes fecais nas amostras de sorvete de chocolate $\left(7^{\mathrm{a}} \mathrm{a} 12^{\mathrm{a}}\right.$ análises) quando comparados à contaminação pelas mesmas bactérias nas amostras de sorvete de creme $\left(1^{\mathrm{a}}\right.$ a $6^{\mathrm{a}}$ análises). Como só a matéria-prima (leite) e o produto final (sorvete) foram analisados, não é possível afirmar categoricamente que o pó sabor de chocolate seja o único responsável pela maior contaminação encontrada, até porque nota-se claramente pelos resultados obtidos que a matéria-prima (leite) utilizada nos meses de coletas de sorvetes de chocolate, estava bem mais contaminada. 
Provavelmente, nos últimos meses de coleta (dezembro, janeiro e fevereiro) o aumento da temperatura ambiente pode ter colaborado para o aumento da contaminação microbiana do leite (Tabelas 1 e 2) e refletido na pior qualidade microbiológica do sorvete (Tabela 3) processado com essa matéria-prima (leite) de qualidade inferior.

Nota-se pelos dados da Tabela 3 que todas as amostras de sorvete de chocolate que se mostraram fora do padrão quando o caldo utilizado foi o CVBLB também se mostraram fora do referido padrão quando se utilizou o caldo EC. Já o inverso não é verdadeiro, ou seja, 5 amostras que seriam colocadas como de acordo com os padrões tolerados de coliformes fecais, quando se utilizou o CVBLB, seriam citadas como fora dos referidos padrões ao se trabalhar com o caldo EC.

As Figuras 16 e 17, ilustram as diferenças na enumeração (NMP) de coliformes fecais em sorvete, utilizando os caldos CVBLB e EC.

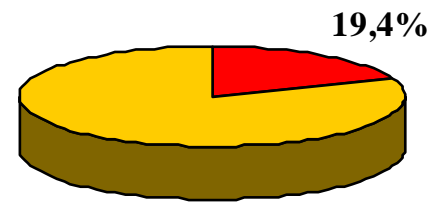

$80,6 \%$

Acima dos padrões $\square$ De acordo comos padrões

Figura 16 - Porcentagem de coliformes fecais em sorvete utilizando o CVBLB

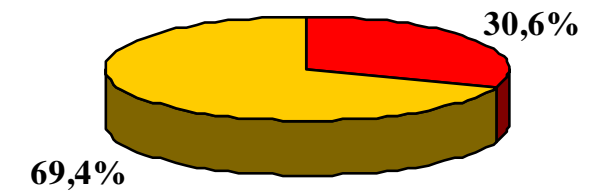

Acima dos padrões $\square$ De acordo com os padrões

Figura 17 - Porcentagem de coliformes fecais em sorvete utilizando o caldo EC 
Fica claro que a recuperação de coliformes fecais em caldo EC foi melhor do que em CVBLB, tendo havido diferença estatística significativa $(\mathrm{p}<0,05)$ entre ambos. $\mathrm{O}$ coeficiente de correlação de Spearman entre os caldos CVBLB e EC foi de 0,78, para as amostras de sorvete analisadas, um valor altamente significativo $(\mathrm{p}<0,0001)$ e que indica uma forte associação entre os dois caldos.

O teste para comparação de médias em dados pareados revelou indícios da existência de diferenças entre as médias verdadeiras de EC e CVBLB $(p<0,05)$. A média maior foi observada no EC o que indica uma maior recuperação dos coliformes fecais por este caldo. Apesar desta diferença, os coeficientes de correlação de 75\% e 78\%, respectivamente observados em leite e sorvete indicam que as medidas são associadas.

Mesmo não havendo na literatura trabalhos que comparem os caldos CVBLB e EC para leite e derivados na detecção de coliformes fecais, Cakir et al. (2001) e Silva \& Gallo (2003) compararam em seus trabalhos a eficiência de diferentes metodologias na estimativa do NMP de coliformes fecais em leite e derivados, porém com meios de cultivo diferentes dos utilizados nesta pesquisa.

Assim, embora as normas da ABNT, sugiram a utilização do CVBLB para coliformes fecais, como a enumeração dessas bactérias foi maior quando se utilizou o caldo EC, sugere-se optar pelo uso deste último.

Valores elevados de coliformes de origem fecal como os encontrados em algumas das amostras de sorvetes analisadas, podem indicar um processamento incorreto, podendo resultar em um alimento de alto risco à saúde pública, sendo, portanto, tais amostras, consideradas em condições inadequadas para o consumo humano.

Em estudo semelhante, Warke et al. (2000) e Richards et al. (2002) analisando coliformes fecais em sorvetes, encontraram níveis de contaminação que variaram de $10^{2}$ a $10^{4} \mathrm{NMP} / \mathrm{g}$, valores estes, que ultrapassaram os limites de segurança prescritos pela legislação e os encontrados nessa pesquisa.

Tamsut \& García (1989), detectaram coliformes fecais em 23\% das amostras de sorvetes analisadas; Coelho (2001) em 45,16\% e Hoffmann et al. (2000) confirmaram em $58,3 \%$ das amostras a presença de coliformes de origem fecal. 
Aragon et al. (2000), verificando a qualidade higiênico-sanitária de sorvetes, observaram que de 11 amostras, 10 (90,9\%) estavam fora dos padrões (Brasil, 1997). Falcão et al. (1983) detectaram contagens superiores a $10^{4} \mathrm{NMP}$ de coliformes fecais/g em 75\% das amostras de sorvetes analisadas.

Coelho (2001) analisando amostras de sorvete, detectou a presença de E. coli em $67,74 \%$ das amostras.

Carvalho et al. (1995) constataram a presença de E. coli somente em sorvetes a base de leite durante todo o tempo de estocagem, o que indica a alta resistência do microrganismo à baixas temperaturas, péssimas condições sanitárias de preparo e o perigo potencial à saúde pública representado por este tipo de produto.

Os coliformes, particularmente a E. coli, são considerados como um indicador recente de contaminação fecal, porém no sorvete, como em muitos outros alimentos, eles sobrevivem e, certas condições, são favoráveis para seu crescimento, com exceção de sorvetes ultracongelados (Rothwell, 1990).

Ao analisarem leite cru e sorvete, Bryan et al. (1992) detectaram mais de $10^{5}$ NMP de coliformes fecais tanto em leite cru quanto em sorvete, onde este último já havia sido submetido ao tratamento térmico.

A presença de coliformes fecais em sorvete a base de leite, principalmente quando em números elevados, indica a alta resistência do microrganismo a baixas temperaturas, bem como más condições higiênico-sanitárias da matéria-prima e de preparo do produto.

Para Vanderzant \& Splittstoesser (1992), a presença de coliformes em misturas pasteurizadas e produtos congelados é uma indicação de contaminação póspasteurização, embora falsos positivos ocorram devido a habilidade de certos microrganismos fermentarem a sacarose.

De acordo com Fenemma et al. (1973), infelizmente a manipulação depois da pasteurização, normalmente serve para somar contaminantes aos produtos.

Segundo a pesquisa realizada por Pinto et al. (2000), os maiores problemas de contaminação estão relacionados com as amostras de sorvetes elaborados com leite, verificando em 50\% das amostras analisadas altos níveis de coliformes de origem fecal. 
Também Kanbakan et al. (2003) detectaram em todas as amostras de sorvetes elaboradas com leite analisadas, a presença de altos níveis de coliformes fecais.

Pinto et al. (2000), ao analisarem sorvetes a base de água e de leite, detectaram maior contaminação nas amostras que continham leite. Segundo os autores, o primeiro fator que contribuiu para isso foi o $\mathrm{pH}$ mais elevado das amostras de sorvete a base de leite. A mesma comparação foi feita por Carvalho et al. (1995), que obtiveram contaminações de até $10^{4} \mathrm{NMP}$ de coliformes fecais/g em sorvetes a base de leite.

Para Vanderzant \& Splittstoesser (1992), a adição de pó sabor e ingredientes como frutas, nozes, e lascas de chocolate à mistura depois da pasteurização pode ser uma fonte de contaminantes. A contaminação pós-pasteurização pode também acontecer pela má limpeza dos equipamentos, pela incorporação de ar, pela reutilização de produtos, e por manipuladores.

Rothwell (1990), salienta que a presença de organismos de origem fecal no sorvete, é invariavelmente devida à contaminação pelo equipamento, o qual não deveria estar devidamente limpo e sanitizado, para que este tipo de contaminação aparecesse.

O mesmo autor ainda ressalta que, a presença de certos organismos como os coliformes, em produtos tratados pelo calor, como o sorvete, também pode indicar um tratamento térmico defeituoso ou inadequado.

Reij \& Den Aantrekker (2004) citam que uma pesquisa realizada pela WHO (1995) na Europa, indicou que quase 25\% das causas de toxinfecção alimentar eram causadas pela recontaminação dos produtos processados. Os fatores mais importantes que contribuíam para a presença de patógenos nos alimentos preparados eram: higiene insatisfatória, contaminação cruzada, processamento ou armazenamento inadequados, equipamento contaminado e contaminação pelo manipulador.

Bryan et al. (1992) mantiveram misturas de sorvete a temperatura ambiente por mais de 4h antes de congelá-las e, após analisá-las, detectaram altas contagens de coliformes. Portanto, nessas condições inadequadas de manutenção da mistura, o sorvete pode se tornar um veículo de toxinfecções, aumentando o risco a cada hora de exposição da mistura à temperatura ambiente. 
Embora o risco de transmissão de doenças seja baixo em sorvetes, algum número mesmo que pequeno de microrganismos que contaminam o produto após a pasteurização serve para alertar o processador de que o risco existe (Marshall \& Arbuckle, 2000).

Os resultados do presente trabalho mostrando contaminação de amostras de leite e de sorvetes, com coliformes totais e coliformes fecais, muitas vezes ultrapassando os limites tolerados pela legislação da ANVISA (Brasil, 2001), servem como alerta aos órgãos competentes, para que uma fiscalização mais rígida seja implementada, a fim de se evitar que a população corra riscos de toxinfecções alimentares pelo consumo de produtos alimentícios inadequados ao consumo humano. São necessários a implementação de boas práticas de fabricação e o monitoramento de pontos críticos e de riscos para a aplicação de medidas que resultem na obtenção de um alimento seguro à população.

\subsection{Salmonella}

Todas as 24 amostras de leite e as 36 amostras de sorvetes analisadas no presente trabalho não apresentaram Salmonella em 25mL ou 25g do produto, atendendo, portanto, a Resolução da ANVISA (Brasil, 2001), que cita como padrão microbiológico a ausência dessa bactéria nessas quantidades dos alimentos.

Resultados semelhantes aos desta pesquisa foram encontrados por Ávila (1994), Tessari \& Cardoso (2002) e Tinôco et al. (2002), para leite pasteurizado quanto à pesquisa de Salmonella, ou seja, a bactéria não foi detectada em todas as amostras analisadas.

Na literatura, são encontradas várias pesquisas com sorvetes, cujos resultados são parecidos aos do presente trabalho, ou seja, ausência de Salmonella em 25 g de sorvete. Podem ser citados: Falcão et al. (1983) em Araraquara; Carvalho et al. (1995) em Minas Gerais; INMETRO (1998) no Rio de Janeiro; Nascimento et al. (1999) em São Luis do Maranhão; Warke et al. (2000) em Mumbai, na Índia; Armondes et al. (2003) em Goiânia e Kanbakan et al. (2003) na Turquia. Entretanto, Hoffmann et al. 
(2000), ao analisarem 12 amostras de sorvetes na cidade de São José do Rio Preto, confirmaram a presença de Salmonella em 9 amostras totalizando o percentual de 75\% de contaminação pelo patógeno. Também, Coelho (2001) analisando 31 amostras de sorvete detectou a presença de Salmonella em 11 amostras, totalizando 35,48\% e Tamsut \& García (1989) trabalhando com 122 amostras de sorvete de creme, encontraram $1(0,8 \%)$ amostra positiva para este patógeno.

Bryan et al. (1992) afirmam que mesmo utilizando a pasteurização para destruir células de Salmonella em sorvete, o mesmo pode ser recontaminado pelos utensílios utilizados como tábuas, facas, conchas e pelas próprias mãos dos manipuladores.

Portanto, as práticas na indústria de laticínios determinam que a segurança do produto envolve a qualidade microbiológica dos ingredientes, a adequação do processo e eliminação de microrganismos, especialmente pela pasteurização e a proteção contra nova contaminação dos produtos pasteurizados por microrganismos patogênicos (Marshall \& Arbuckle, 2000).

Cotton \& White (1992), ao analisarem amostras de seis plantas de processamento de leite e de quatro plantas de processamento de sorvete, não detectaram Salmonella spp. em nenhuma das amostras. Ressaltaram a importância de controlar a matéria-prima, quanto às análises de patógenos, o que sem dúvida, é de grande importância na garantia da qualidade do produto final.

O fabricante de sorvetes não pode contar que o processo de congelamento seja letal para os microrganismos patogênicos. Os sorvetes são produtos relativamente seguros, porém as chances de contaminação depois da pasteurização não são insignificantes (Marshall \& Arbuckle, 2000).

Os derivados do leite, como os sorvetes, podem representar riscos à saúde pública se não forem bem controlados desde a matéria-prima até seu processamento. Hoffmann et al. (1995) e Hoffmann et al. (2000), ao analisarem a qualidade higiênicosanitária de sorvetes artesanais, constataram que as amostras estavam em desacordo com um ou mais padrões microbiológicos da legislação brasileira. Inclusive detectaram a presença de Salmonella spp, o que já é suficiente para classificá-los como “produtos 
potencialmente capazes de causar enfermidades transmitidas por alimentos” e, portanto, “produtos impróprios para o consumo humano”.

\subsection{Staphylococcus coagulase-positiva}

Das 24 amostras de leite analisadas, apenas 1 (4,2\%) mostrou-se contaminada por Staphylococcus coagulase-positiva e com valor de 1,4 x $10^{3} \mathrm{UFC} / \mathrm{mL}$. Em relação as 36 amostras de sorvetes analisadas, 2 delas (5,6\%) mostraram-se contaminadas com valores de 6,0 x $10^{2}$ e 9,0 × $10^{2}$ UFC/g e, portanto, com contaminação acima do valor máximo tolerado pela legislação da ANVISA (Brasil, 2001) que é de 5,0 x 10² UFC/g de sorvete.

Algumas espécies de Staphylococcus produzem enterotoxinas estáveis à pasteurização; assim o crescimento destes organismos no leite cru deve ser prevenido, assegurando com isso a boa qualidade do leite pasteurizado. Além da higiene, normalmente o leite estará seguro se mantido abaixo de $10^{\circ} \mathrm{C}$ (Nelson, 1981).

Na literatura, o sorvete aparece como alimento envolvido em surtos de toxinfecções; no entanto, os dados obtidos no presente trabalho, para as determinações microbiológicas realizadas para Staphylococcus coagulase-positiva, mostram que apesar de ser um produto artesanal e, portanto, mais susceptível à contaminação, o mesmo apresentou qualidade satisfatória para consumo humano em 94,4\% das amostras analisadas.

Percentuais muito próximos aos dessa pesquisa, foram encontrados por Tamminga et al. (1980) ao analisarem sorvetes, detectando $S$. aureus em 7,8\% das amostras, com valores de 10 a 2,2 x $10^{4} \mathrm{UFC} / \mathrm{g}$

Outro levantamento que mostrou dados otimistas quanto a contaminação de sorvetes por S. aureus, foi realizado pelo INMETRO (1998) no Rio de Janeiro, onde $100 \%$ das amostras analisadas, se mostraram isentas desse patógeno, o que coloca tais produtos em condições sanitárias satisfatórias.

No entanto, na literatura encontram-se vários trabalhos que mostram contaminações por S. aureus em sorvetes, com valores bem superiores aos percentuais 
encontrados na presente pesquisa. Armondes et al. (2003) encontraram 10\% das amostras de sorvete analisadas com contaminações por $S$. aureus entre $10^{3}$ e $10^{4} \mathrm{UFC} / \mathrm{g}$. Falcão et al. (1983) detectaram S. aureus em 16,6\% das amostras de sorvetes analisadas com contagens de até $10^{3} \mathrm{UFC} / \mathrm{g}$. Kanbakan et al. (2003) encontraram S. aureus em 25\% das amostras analisadas. Richards et al. (2002) analisando amostras de sorvete encontraram S. aureus em 37,5\% das mesmas, com contagens de até $10^{3} \mathrm{UFC} / \mathrm{g}$.

Coelho (2001) analisando 31 amostras de sorvetes, detectou a presença de $S$. aureus em $38,71 \%$ das amostras, variando de $10^{3}$ a $10^{6}$, classificando-as como produtos em condições sanitárias insatisfatórias e, portanto, produtos impróprios para o consumo humano.

Tamsut \& García (1989) analisando amostras de sorvete de creme, detectaram em $68 \%$ a presença de $S$. aureus em números que variaram de $10^{2}$ a $10^{4} \mathrm{UFC} / \mathrm{g}$. Hoffmann et al. (2000) encontraram em $75 \%$ das amostras de sorvetes analisadas a presença de $S$. aureus, obtendo valores entre $2,5 \times 10^{2}$ e 9,4 x $10^{6} \mathrm{UFC} / \mathrm{g}$ e, portanto, valores como os últimos $\left(10^{6}\right)$ onde toxinas já podem estar presentes no alimento. Warke et al. (2000) ao analisarem 30 amostras comerciais de sorvete, obtiveram contaminação por S. aureus em $100 \%$ das amostras.

Pelos resultados mostrados pelos trabalhos encontrados na literatura, fica claro que a contaminação de sorvetes por $S$. aureus ocorre e pode acontecer em números elevados, confirmando ser um alimento de risco para o consumo humano, quanto a possibilidade de intoxicação através de toxinas de $S$. aureus. Tais citações, contradizem os resultados obtidos na presente pesquisa, onde apenas 5,6\% das amostras de sorvete analisadas se mostraram contaminadas por Staphylococcus coagulase positiva e com números entre $10^{2}$ e $10^{3} \mathrm{UFC} / \mathrm{g}$, ou seja, baixos e que dificilmente estariam sendo responsáveis por intoxicação alimentar. Porém, o fato de ter sido detectado Staphylococcus coagulase positiva em 5,6\% das amostras analisadas com valores ligeiramente superiores aos permitidos pela legislação, aliado ao fato da presença de coliformes fecais no produto, deixa clara a necessidade de implementação de boas práticas e monitoramento de pontos críticos e de riscos, para que medidas adequadas 
sejam tomadas a fim de se obter um produto de melhor qualidade microbiológica e seguro à população. 


\section{CONCLUSÕES}

- Das 24 amostras de leite pasteurizado tipo C analisadas, 14 (58,3\%) apresentaram contaminação por coliformes a $45^{\circ} \mathrm{C}$ (fecais) acima dos padrões legais vigentes, quando utilizado o CVBLB e 17 (70,8\%) quando o caldo utilizado foi o EC, sendo tais amostras consideradas como produtos em condições sanitárias insatisfatórias para o consumo humano.

- Das 36 amostras de sorvetes analisadas, 7 (19,4\%) apresentaram contaminação por coliformes a $45^{\circ} \mathrm{C}$ acima dos padrões legais vigentes, quando se utilizou o CVBLB e 11 (30,6\%) quando se utilizou o caldo EC, o que coloca essas amostras como produtos em condições sanitárias insatisfatórias para o consumo humano.

- A recuperação de coliformes fecais quando se utilizou o caldo EC foi melhor do que quando se utilizou o CVBLB a $45^{\circ} \mathrm{C}$. Assim, embora a ABNT sugira o uso do CVBLB para a determinação de coliformes a $45^{\circ} \mathrm{C}$, recomenda-se o uso do caldo EC, como acontece para outros alimentos, como melhor caldo para essa determinação. Tal recomendação, na presente pesquisa, é justificada pela diferença estatística significativa $(\mathrm{p}<0,05)$ entre os caldos utilizados.

- A correlação de Spearman entre os caldos EC e CVBLB foi de 0,75 para o leite e de 0,78 para o sorvete. Os coeficientes de correlação de 75\% e 78\%, respectivamente observados em leite e sorvete, indicam que as medidas são associadas.

- A má qualidade microbiológica do leite utilizado para a produção de sorvetes, onde 58,3\% (CVBLB) e 70,8\% (EC) das amostras estavam contaminadas com coliformes fecais em níveis superiores aos permitidos pela legislação, acabou se refletindo na obtenção de elevados percentuais de sorvetes também contaminados por 
essas bactérias. Fica clara a necessidade de uma boa qualidade microbiológica da matéria-prima (leite) para a obtenção de um bom derivado.

- Das 24 amostras de leite pasteurizado tipo C analisadas, 1 (4,2\%) apresentou contaminação por Staphylococcus coagulase-positiva em níveis superiores a $10^{2}$ UFC/mL e 2 (5,6\%) das 36 amostras de sorvetes analisadas apresentaram contaminação por essas bactérias em níveis superiores ao tolerado pela legislação que é de 5,0 x $10^{2}$ UFC/g de sorvete. Tais amostras contaminadas por essas bactérias são consideradas como produtos impróprios para o consumo humano.

- Todas as amostras de leite e de sorvete analisadas, não apresentaram contaminação por Salmonella em $25 \mathrm{~mL}$ ou $25 \mathrm{~g}$ do produto, o que as coloca em acordo com os padrões legais vigentes para este parâmetro microbiológico. 


\section{REFERÊNCIAS BIBLIOGRÁFICAS}

ARAGON, L.C.; BOMBO, A.J.; SILVA, M.G. Pesquisa de Staphylococcus aureus e de indicadores higiênico-sanitários em leite e derivados comercializados na cidade de Botucatu e detecção de toxinas a partir dos alimentos. 2000. http://www.usp.br/siicusp/80siicusp/resumos/ficha 1989.htm (18 jul. 2004)

ARMONDES, M.P.; ISSY, P.N.; ANDRÉ, M.C.D.P.B. Aspectos higiênico-sanitários de sorvetes e caldas de sorvetes, produzidos artesanalmente na cidade de Goiânia, GO. Higiene Alimentar, v.17, n.107, p.86-94, abr. 2003.

ASSOCIAÇÃO BRASILEIRA DE NORMAS TÉCNICAS (ABNT). Bactérias coliformes totais, coliformes fecais e Escherichia coli em alimentos determinação do número mais provável. 1991. MB nº 3463. Rio de Janeiro, 1991. $7 p$.

ASSOCIATION OF OFFICIAL ANALYTICAL CHEMISTS (AOAC). Official methods of analysis. 13.ed. Arlington, 2000. 1v.

ÁVILA, C.R. de. Pesquisa de Salmonella spp. em leite cru, leite pasteurizado tipo C e queijo Minas frescal comercializados no município de Piracicaba - SP. Piracicaba, 1994. 84p. Dissertação (Mestrado) - Escola Superior de Agricultura "Luiz de Queiros”, Universidade de São Paulo. 
BARROS, V.R.M. de; JARDIM, F.S.F.; MACHADO, P.F. et al. Quebra do paradigma da qualidade do leite $\mathrm{C}$, recebido em usina de beneficiamento sob inspeção federal, em Catanduva - SP. Higiene Alimentar, v.13, n.65, p.6-9, out.1999.

BRABES, K.C. da S. Detecção de Staphylococcus spp e suas enterotoxinas em leite proveniente de bovinos leiteiros com mastite. Lavras, 1999. 77p. Dissertação (Mestrado) - Universidade Federal de Lavras.

BRAMLEY, A.J.; McKINNON, C.H. The microbiology of raw milk. In: ROTHWELL, R.K. (Ed.). Dairy microbiology. London: Elsevier, 1990. v.1, cap.5, p.163-207.

BRASIL. Ministério da Agricultura, Pecuária e Abastecimento. Regulamento da inspeção industrial e sanitária de produtos de origem animal (RIISPOA). Brasília, 1997. 214p.

BRASIL. Ministério da Agricultura, Pecuária e Abastecimento. Secretaria de Defesa Agropecuária. Departamento de Defesa Animal. Coordenação de Laboratório Animal. Ofício AUP/DOI/DIPOA n ${ }^{\circ}$ 3836, de 31 de outubro de 2002. Manual de análise microbiológica de produtos de origem animal e água. Brasília, 2002. 196p.

BRASIL. Ministério da Saúde. Agência Nacional de Vigilância Sanitária (ANVISA). Portaria no 451, de 19 de setembro de 1997. Diário Oficial, n.124-E, 02 jul. 1998. Seção 1, p.6. Aprova o regulamento técnico e princípios gerais para o estabelecimento de critérios e padrões microbiológicos para alimentos e seus anexos I, II e III. 
BRASIL. Ministério da Saúde. Agência Nacional de Vigilância Sanitária (ANVISA). Resolução - RDC $\mathbf{n}^{0}$ 12, de 02 de janeiro de 2001: regulamento técnico sobre padrões microbiológicos em alimentos. http://www.anvisa.gov.br/legis/resol/12_01rdc.htm (21 fev. 2002)

BRASIL. Ministério da Saúde. Comissão Nacional de Normas e Padrões para Alimentos. Resolução no 4/78 da Portaria n ${ }^{0}$ 204/ Bsb de 04 de maio de 1978. In: ASSOCIAÇÃO BRASILEIRA DAS INDÚSTRIAS DA ALIMENTAÇÃO. Compêndio da legislação de alimentos. rev. 3. São Paulo: ABIA, 1996. v.1/A, p.7.38(78) - 7.43(78).

BRYAN, F.L.; TEUFEL, P.; RIAZ, S. et al. Hazards and critical control points of street-vending operations in a mountain resort town in Pakistan. Journal of Food Protection, v.55, n.9, p.701-707, 1992.

BUYSER, M.L. de; DUFOUR, B.; MAIRE, M.; LAFARGE, V. Implication of milk and milk products in food-borne diseases in France and in different industrialised countries. International Journal of Food Microbiology, v.67, p.1-17, 2001.

CAKIR, I.; DOGAN, H.B.; HALKMAN, A.K.; WOROBO, R.W. An alternative approach for enumeration of Escherichia coli in foods. International Journal of Food Microbiology, v.68, p.217-223, 2001.

CARVALHO, E.P. de; ABREU, L.R. de; CARVALHO, M.C. Estudo de alguns aspectos microbiológicos em sorvetes não pasteurizados. Revista do Instituto de Laticínios “Cândido Tostes”, v.50, n.291, p.43-49, 1995.

CASTILHO, C.M.C. Sorvete: a delícia que alimenta. Leite \& Derivados, v.1, n.6, p.42-43, 1992. 
CHAVES, J.B.P. Noções de microbiologia e conservação de alimentos. Viçosa: Universidade Federal de Viçosa, 1993. 114p.

COELHO, A.R. Qualidade microbiológica e ocorrência de leveduras em diferentes tipos de sorvete. São José do Rio Preto, 2001. 106p. Dissertação (Mestrado) Instituto de Biociências, Letras e Ciências Exatas, Universidade Estadual Paulista “Júlio de Mesquita Filho".

COTTON, L.N.; WHITE, C.H. Listeria monocytogenes, Yersinia enterocolitica and Salmonella in Dairy Plant Environments. Journal of Dairy Science, v.7, n.1, p.1218, 1992.

DAVIS, B.D.; DULBECCO, R.; EISEN, H.N. et al. Microbiologia: infecções bacterianas e micóticas. São Paulo: Edart, 1973. v.3.

ELEY, R. Intoxicaciones alimentarias de etiologia microbiana. Acribia: Zaragoza, 1994. 208p.

FALCÃO, D.P.; SALGADO, G.F.; NISHIDA, N.K. et al. Exame microbiológico de sorvetes não pasteurizados. Revista de Saúde Pública, v.17, n.1, p.2-8, 1983.

FENEMMA, O.R.; POWRIE, W.D.; MARTH, E.H. Low-temperature preservation of foods and living matter. New York: Marcel Dekker, 1973. 598p.

FRANCO, B.D.G. de M.; LANDGRAF, M. Microbiologia dos alimentos. São Paulo: Atheneu, 1996. 182p.

FRANK, H.K. Dictionary of food microbiology. Lancaster: Technomic, 1992. 298p. 
FRAZIER, W.C.; WESTHOFF, D.C. Microbiología de los alimentos. 4.ed. Acribia: Zaragoza, 1993. 681p.

FREITAS, J. de A.; OLIVEIRA, J.P. de; SUMBO, F.D. et al. Características físicoquímicas e microbiológicas do leite fluido exposto ao consumo na cidade de Belém, Pará. Higiene Alimentar, v.16, n.100, p.89-96, 2002.

GOMES, H. de A. Ocorrência de Staphylococcus aureus e produção de enterotoxinas por linhagens isoladas a partir de leite cru, leite pasteurizado tipo c e queijo "Minas frescal”, comercializados em Piracicaba - S.P. Piracicaba, 1994. 124p. Dissertação (Mestrado) - Escola Superior de Agricultura “Luiz de Queiroz”, Universidade de São Paulo.

GUADAGNOLI, C.A. Controle da qualidade na indústria de sorvetes. Leite \& Derivados, v.1, n.6, p.33-34, 1992.

HALÁSZ, L. (Coord.); PINHEIRO, C.P.; ARAÚJO FILHO, E.N. de; SATO, G.T. et al. Refrigeração. São Paulo: Secretaria da Indústria, Comércio, Ciência e Tecnologia, 1982. 220p.

HATCHER, L.; STEPANSKY, E.J. A step-by-step approach to using the SAS system for univariate and multivariate statistics. Cary: SAS Institute, 1994. 576p.

HENNESSY, T.W.; HEDBERG, C.W.; SLUTSKER, L. et al. A national outbreak of Salmonella enteritidis infections from ice cream. New England Journal of Medicine, v.20, n.334, p.1281-1286, May 1996.

HOBBS, B.C.; ROBERTS, D. Toxinfecções e controle higiênico-sanitário de alimentos. São Paulo: Varela, 1999. 376p. 
HOFFMANN, F.L.; GARCIA-CRUZ, C.H.; VINTURIM, T.M. et al. Qualidade higiênico-sanitária de sorvetes comercializados na cidade de São José do Rio PretoSP-Brasil. Boletim do Centro de Pesquisa e Processamento de Alimentos, v.13, n.2, p.99-108, jul./dez. 1995.

HOFFMANN, F.L.; PENNA, A.L.B.; COELHO, A.R. Qualidade higiênico-sanitária de sorvetes comercializados na cidade de São José do Rio Preto-SP-Brasil. Higiene Alimentar, v.11, n.76, p.62-68, set. 2000.

INSTITUTO NACIONAL DE METROLOGIA, NORMALIZAÇÃO E QUALIDADE $\begin{array}{lll}\text { INDUSTRIAL } & \text { (INMETRO). } & \text { Sorvete. }\end{array}$ http://www.INMETRO.gov/consumidor/produtos/sorvete.asp 1998. (27 maio 2003)

JAKABI, M.; FRANCO, B.D.G.M. Frequência de isolamento de cepas de E. coli patogênica em alimentos de origem animal. Ciência e Tecnologia de Alimentos, v.11, n.2, p.170-181, jul./dez. 1991.

KANBAKAN, U.; CÔN, A.H.; AYAR, A. Determination of microbiological contamination sources during ice cream production in Denizli, Turkey. Food Control, v.30, p.1-8, 2003.

LEITÃO, M. F. de F. Microbiologia de alimentos. In: ROITMAM, I.; TRAVASSOS, L. R.; AZEVEDO, J.L. Tratado de microbiologia. São Paulo: Manole, 1988. v.1, p.3-81.

MARSHALL, R.T.; ARBUCKLE, W.S. Ice cream. 5.ed. Maryland: Aspen Publishers, 2000. 349p.

MOSQUIM, M.C.A. Fabricando sorvetes com qualidade. São Paulo: Fonte, 1999. 120p. 
MURPHY, S.C.; BOOR, K.J. Trouble-shooting sources and causes of high bacteria counts in raw milk. Dairy, Food and Environmental Sanitation, v.20, n.8, p.606611, 2000.

NASCIMENTO, A.R.; VIÉGAS, R.G.; CARVALHO, P.A.B. et al. Avaliação microbiológica de gelados comestíveis (picolé), de indústrias de pequeno porte da cidade de São Luis - MA. Higiene Alimentar, v.13, n.64, p.58-61, 1999.

NASCIMENTO, M.R. do; STAMFORD, T.L.M. Incidência de Escherichia coli O157:H7 em alimentos. Higiene Alimentar, v.14, n.70, p.32-35, mar. 2000.

NELSON, F.E. The microbiology of market milk. In: ROBINSON, R.K. (Ed.). Dairy microbiology: the microbiology of milk. London: Elsevier, 1981. v.1, cap.5, p.165208.

OVIEDO, M.T.P. Resistência de psicrotrófico acidificante isolado de leite cru a agentes sanitizantes. Viçosa, 1996. 51p. Dissertação (M.S.) - Universidade Federal de Viçosa.

PINTO, M.F.; PONSANO, E.H.G.; DELBEM, A.C.B. et al. Condição higiênicosanitária de sorvetes fabricados por indústrias artesanais no município de Araçatuba - S.P. Higiene Alimentar, v.14, n.72, p.50-52, 2000.

REIJ, M.W.; DEN AANTREKKER, E.D. Recontamination as a source of pathogens in processed foods. International Journal of Food Microbiology, v.91, p.1-11, 2004.

RIBEIRO, M.G.; PINTO, J.P. de A.N.; SILVA, E.O.T.R. Escherichia coli O157:H7 de hambúrguer, leite e outros gêneros alimentícios à colite hemorrágica e síndrome urêmico-hemolítica. Higiene Alimentar, v.13, n.66/67, p.88-99, nov./dez. 1999. 
RICHARDS, N.S.P.S.; SILVA, M.E. da; PEREIRA, D. et al. Avaliação das condições higiênico-sanitárias de sorvetes tipo italiano (soft), comercializados na cidade de São Leopoldo, RS. Higiene Alimentar, v.16, n.92/93, p.57-62, jan./fev. 2002.

ROBERTS, D.; HOOPER, W.; GREENWOOD, M. Microbiologia práctica de los alimentos: métodos para el examen de microrganismos de los alimentos de interés para la salud pública. Zaragoza: Acribia, 2000. 276p.

ROITMAN, I.; TRAVASSOS, R.; AZEVEDO, J.L. (Ed.). Tratado de microbiologia. São Paulo: Manole, 1988. 186p.

ROTHWELL, J. Microbiology of ice cream and related products. In: ROBINSON, R. K. (Ed.). Dairy microbiology: the microbiology of milk products. 2.ed. London: Elsevier, 1990. v.2, cap.1, p.1-40.

SILVA, M.C. da; GALLO, C.R. Avaliação da qualidade microbiológica de alimentos com a utilização de metodologias convencionais e do sistema simplate. Higiene Alimentar, v.17, n.107, p.75-85, abr. 2003.

SILVA, N. da; NETO, R.C.; JUNQUEIRA, V.C.A. et al. Manual de métodos de análise microbiológica da água. Campinas: ITAL, 2000. 99p.

STATISTICAL ANALYSIS SYSTEM INSTITUTE. The SAS system (software). Release 8.2. Cary, 2001.

TAMMINGA, S.K.; BEUMER, R.R.; KAMPELMACHER, E.H. Bacteriological examination of ice-cream in the Netherlands: comparative studies on methods. Journal of Applied Bacteriology, v.49, n.2, p.239-253, Oct. 1980. 
TAMSUT, L.S. de; GARCÍA, C.E. Calidad microbiológica de los helados de crema elaborados en Caracas, Venezuela. Archivos Latinoamericanos de Nutricion, v.39, n.1, p.47-56, Mar. 1989.

TESSARI, E.N.C.; CARDOSO, A.L.S.P. Qualidade microbiológica do leite tipo "A" pasteurizado, comercializado na cidade de Descalvado, SP. Higiene Alimentar, v.16, n.96, p.65-68, maio 2002.

THOMAS, S.B. Técnicas bacteriológicas para el control lactológico. Acribia: Zaragoza, 1971. 257p.

TINÔCO, A.L. de A.; COELHO, M. do S.L.; PINTO, P.S. de A. et al. Estudo microbiológico comparativo de leites pasteurizados em estabelecimentos com inspeção federal e em fazendas. Higiene Alimentar, v.16, n.96, p.88-93, maio 2002.

VANDERZANT, C.; SPLITTSTOESSER, D.F. Compendium of methods for the microbiological examination of foods. 3.ed. Washington: APHA, 1992. 1219p.

VARNAM, A.H.; SUTHERLAND, J.P. Milk and milk products: technology, chemistry and microbiology. London: Chapman \& Hall, 1994. 451p.

WARKE, R.; KAMAT, A; KAMAT, M. Incidence of pathogenic psychrotrophs in ice creams sold in some retail outlets in Mumbai, Índia. Food Control, v.11, p.77-83, 2000.

WORLD HEALTH ORGANIZATION (WHO). Sixth report of WHO surveillance programme for control of foodborne infections and intoxications in Europe. Berlin: FAO, 1995. 1v. 